Supplement of

\title{
Decadal evolution of ship emissions in China from 2004 to 2013 by using an integrated AIS-based approach and projection to 2040
}

Cheng Li et al.

Correspondence to: J. Zheng (zheng.junyu@ gmail.com)

The copyright of individual parts of the supplement might differ from the CC BY 4.0 License. 


\section{Abbreviations}

AB: Auxiliary Boilers

AE: Auxiliary Engine

AIS: Automatic Identification System

5 BC: Black Carbon

CCTD: Statistics Communique of China on the Traffic and Transportation Industry Development

CO: Carbon monoxide

CPSY: China Port Statistics Yearbook

CVs: Coastal Vessels

10 DECAs: Domestic Emission Control Areas

DWT: Dead Weight Tonnage

ECA: Emission Control Area

EGR: Exhaust Gas Recirculation

GDP: Gross Domestic Product

15 HC: Hydrocarbon

HFO: Heavy Fuel Oil

ICF international: A global Consulting and Technology Services Company

IMO: International Maritime Organization

LNG: Liquefied Natural Gas

20 LRS: Lloyd's Register of Ships

MD: Marine Department

MDO: Marine Diesel Oil

ME: Main Engine

MEIC: Multi-resolution Emission Inventory for China

25 NECA: NOx-DECA, Domestic Emission Control Areas for $\mathrm{NO}_{\mathrm{x}}$ Control

Nm: Nautical Miles

NMVOC: Non-methane Volatile Organic Compounds

NOx: Nitrogen oxide 
OGVs: Ocean-going Vessels

OC: Organic Carbon

PM: Particulate Matter

PoLa: Los Angeles and Long Beach

5 PRD: Pearl River Delta Region

QAQC: Quality Assurance and Quality Control

RVs: River Vessels

SCR: Selective Catalyst Reduction

SECA: $\mathrm{SO}_{2}$-DECA, Domestic Emission Control Areas for $\mathrm{SO}_{2}$ Control

10 SI: Supporting Information

SO2: Sulfur dioxide

tce/10kt: Ton of Standard Coal Equivalent per 10 Kiloton

U.S.EPA: United States Environment Protection Agency

VAN: Vessel Arrived Number

15 WHO: world health organization

YRD: Yangtze River Delta Region 


\section{Domain and ship categorization}

According to the "United Nations convention on the law of the sea" approved by United Nations conference on the third law of the sea in 1982, which indicated that 200 nautical miles (Nm) exclusive economic zone (EEZ) belongs to the scope of the jurisdiction of the state, further explain in article 56 of the convention mentioned the right

5 regulation of EEZ including the jurisdiction on the area of artificial islands, installations and science research and Marine environmental protection fields, that is to say the research domain of ship emissions in China expand to 200 $\mathrm{Nm}$ zone is acceptable. However, science research does not mean the legislative power, have jurisdiction over 12 Nm of ship emissions control area (ECA) needs to be approved by IMO, e.g., Beihai ECA, Mediterranean ECA. The scope of these international ECAs are $200 \mathrm{Nm}$, which support the domain in this study, and also enhance the referable of this study. By the way, the domain chosen in this study reflects our focus on densely populated areas and does not represent any national boundaries.

There were $18000 \mathrm{~km}$ coastline covered 31760 harbors in this region, which contains 5675 coast harbors and 2001 10kt carrier harbors. More detail for 10kt carrier harbors in table SI-1, SI-2.

Table SI-1 the distribution of 10kt carrier ports in China, 2013

\begin{tabular}{cccc}
\hline Port size & Coast port & River port & Total \\
\hline Total & 1607 & 394 & 2001 \\
{$[10 \mathrm{kt}, 30 \mathrm{kt}]$} & 567 & 169 & 736 \\
{$[30 \mathrm{kt}, 50 \mathrm{kt}]$} & 254 & 102 & 356 \\
{$[50 \mathrm{kt}, 100 \mathrm{kt}]$} & 532 & 116 & 648 \\
$\geq 100 \mathrm{kt}$ & 254 & 7 & 261 \\
\hline
\end{tabular}

Table SI-2 the distribution of the function of 10kt carrier ports in China, 2013

\begin{tabular}{ccccccccccc}
\hline Function & Container & Coal & Metal & Crude & Oil & Chemical & Food & General & General & Total \\
& & & ore & Oil & product & & & bulk & cargo & \\
\hline Number & 321 & 206 & 61 & 68 & 124 & 157 & 6 & 414 & 345 & 2001 \\
\hline
\end{tabular}

Four sub-categories were classified by cargo types, i.e. container ships carrying containers, cargo ships carrying dry bulk like ore, construction materials, coal and its products, tankers carrying chemicals, gas, oil and its products, and others. More detailed information for sub-categorizes of DWT. 
Table SI-3 Classification Basis of Different Operation Modes

\begin{tabular}{lll}
\hline \multicolumn{1}{c}{ Operation Mode } & \multicolumn{1}{c}{ Description } & \multicolumn{1}{c}{ Ship Speed } \\
\hline Cruise (At sea) & $\begin{array}{l}\text { Ship operating at service speed, usually in inland waters, } \\
\text { offshore open waters or broad fairways }\end{array}$ & Over 8 knots \\
Maneuvering & $\begin{array}{l}\text { Ship operating at lower speed as it approaches } \\
\text { berth/pier/dock or anchorage }\end{array}$ & 1 to below 8 knots \\
Hotelling (At berth) & $\begin{array}{l}\text { Ship at berth or anchored with propulsion engines switched } \\
\text { off }\end{array}$ & Below 1 knot \\
\hline
\end{tabular}

*knot is a unit of sailing speed measuring, $1 \mathrm{knot}=1$ sea mile/hour; sea mile is a unit of distance measuring, 1 sea mile $=1.852 \mathrm{~km}$ (China Standard), so $1 \mathrm{knot} \approx 1.852 \mathrm{~km} / \mathrm{h}$.

Table SI-4 DWT Classification of Different Ship Types

\begin{tabular}{|c|c|c|c|c|c|}
\hline OGV & $\mathrm{CV}$ & RV & OGV & $\mathrm{CV}$ & RV \\
\hline Container & Container & Container & Chemical Tanker & Chemical Tanker & Chemical Tanker \\
\hline DWT <10000 & DWT $<3000$ & $\mathrm{DWT}<500$ & DWT $<5000$ & DWT $<3000$ & $\mathrm{DWT}<500$ \\
\hline DWT 10000-19999 & DWT 3000-4999 & DWT 500-1000 & DWT5000-9999 & DWT 3000-5000 & DWT $>500$ \\
\hline DWT 20000-29999 & DWT 5000-9999 & DWT $>1000$ & DWT 10000-19999 & DWT 5000-9999 & \\
\hline DWT 30000-39999 & DWT >10000 & & DWT 20000-39999 & DWT $>=10000$ & \\
\hline DWT 40000-49999 & & & DWT $>=40000$ & & \\
\hline \multirow[t]{2}{*}{ DWT 50000-74999 } & & & Conventional & Conventional & Conventional \\
\hline & & & Cargo Ship & Cargo Ship & Cargo Ship \\
\hline DWT 75000-99999 & & & DWT $<2000$ & DWT $<5000$ & $\mathrm{DWT}<500$ \\
\hline DWT $>=100000$ & & & DWT 2000-4999 & DWT 5000-9999 & DWT 500-1000 \\
\hline Gas Tanker & Gas Tanker & Gas Tanker & DWT 5000-9999 & DWT 10000-29999 & DWT $>1000$ \\
\hline DWT $<5000$ & DWT $<3000$ & $\mathrm{DWT}<500$ & DWT 10000-29999 & DWT $>=30000$ & \\
\hline DWT 5000-9999 & DWT 3000-4999 & $\mathrm{DWT}>500$ & DWT $>=30000$ & & \\
\hline DWT 10000-19999 & DWT 5000-9999 & & Dry Bulk Carrier & Dry Bulk Carrier & Dry Bulk Carrier \\
\hline DWT 20000-39999 & DWT $>=10000$ & & DWT $<10000$ & DWT $<3000$ & $\mathrm{DWT}<500$ \\
\hline DWT $>=40000$ & & & DWT 10000-29999 & DWT 3000-4999 & DWT 500-1000 \\
\hline Oil Tanker & Oil Tanker & Oil Tanker & DWT 30000-59999 & DWT 5000-9999 & $\mathrm{DWT}>1000$ \\
\hline DWT <10000 & DWT $<3000$ & $\mathrm{DWT}<500$ & DWT 60000-99999 & DWT $>=10000$ & \\
\hline DWT 10000-29999 & DWT 3000-4999 & $\mathrm{DWT}>500$ & DWT $>=100000$ & & \\
\hline DWT 30000-59999 & DWT 5000-9999 & & Tug & Tug & Tug \\
\hline DWT 60000-119999 & DWT $>=10000$ & & Passenger ship & Passenger ship & Passenger ship \\
\hline \multirow[t]{2}{*}{ DWT $>=120000$} & & & Fishing ship & Fishing ship & Fishing ship \\
\hline & & & Others & Others & Others \\
\hline
\end{tabular}




\section{Potential influence of transit ships}

We did roughly estimate the contribution from passing ships, and concluded that their contribution is relatively low but with potentially high uncertainties. Therefore, we decide to exclude it into this study to avoid negative impact on the results. The research domain is $200 \mathrm{Nm}$ to the coast of Mainland China. The main routes in this domain include all routes from/to Chinese ports and the passing routes, mainly from Busan, Korea to Southeast Asia (Busan route) and from Taiwan to destinations other than Mainland China ports (Taiwan route). In order to study the fraction of Busan route and Taiwan route in our research domain, we extracted a real-time AIS map, and highlighted the passing ship routes by red lines (Fig. SI-1).

There were 368 shipping route from/to Korea in 2013, including 85 Southeast Asia routes and 26 Europe routes. As the throughput of Busan port accounted for $75.4 \%$ of total throughput (17686kt) in Korea, we estimated that Busan route roughly accounted for $7100 \mathrm{kt}$ throughput. With around $800 \mathrm{Nm}$ passing distance in our research domain, we estimated the fuel consumption from Busan route was around 70kt HFO. The total throughput in Taiwan was 14 million TEU in 2013, including 2.5 million TEU between Taiwan and Mainland China. Therefore, Taiwan route contributed around 11.5 million TEU. If we assume $1 \mathrm{TEU}=15 \mathrm{t}$ and the average travel distance was $500 \mathrm{Nm}$, the fuel consumption from Taiwan route was around 1070kt HFO. Therefore, the total consumption of Busan route and Taiwan route was around 1140kt HFO, only $7 \%$ of total fuel consumption in our research domain. Therefore, we believe excluding the passing route would not significantly impact our analysis results.

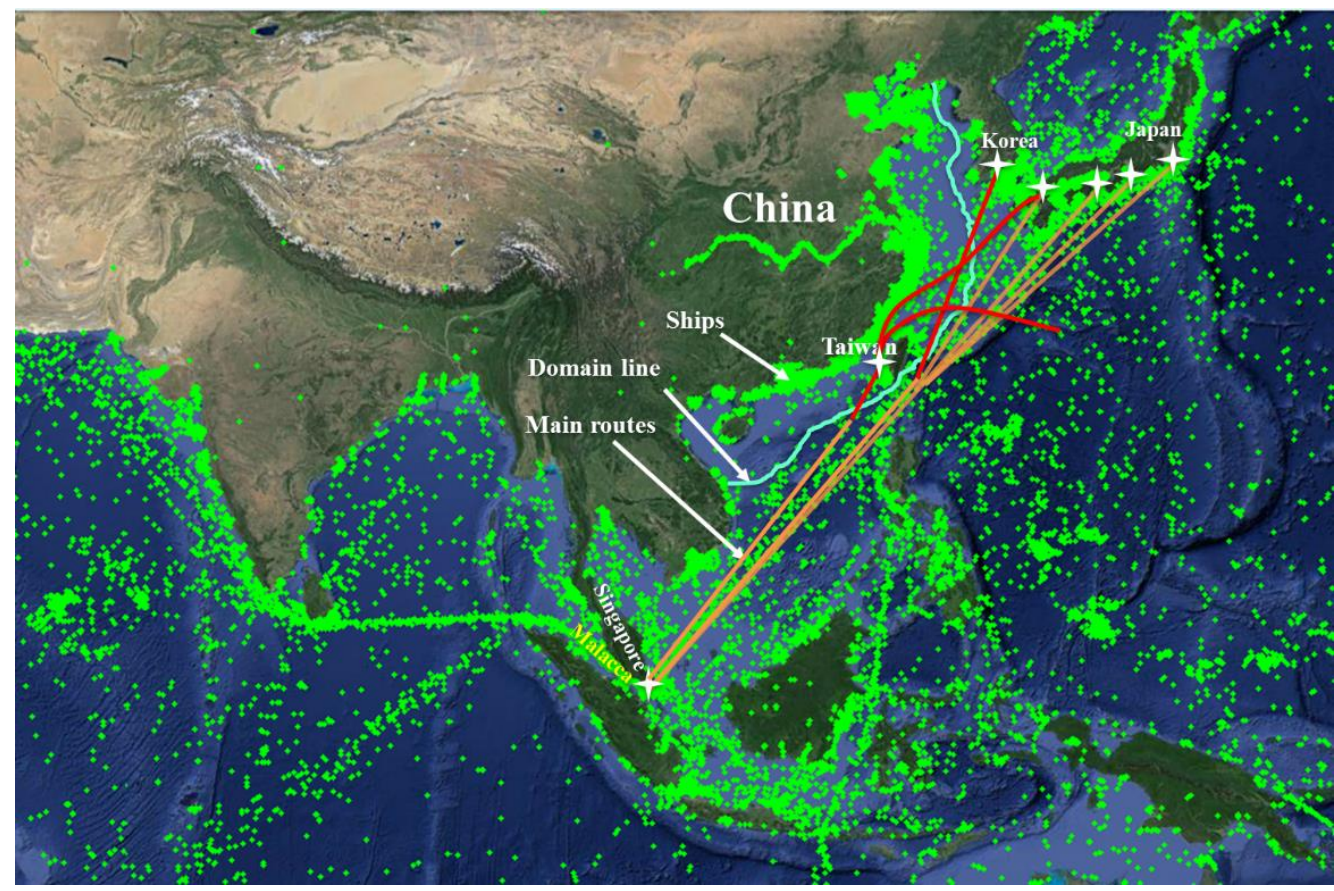

Fig. SI-1 Major shipping routes extracted from a real-time AIS digital map 


\section{Transport volume information}

Transport volume is the real weight of transport cargo for a period time, different statistic approaches used for the Yangtze River ports and other coast ports, the former statistics output cargo weight, and the later statistics input cargo weight. Transport volume statistics from the Chinese National Statistics Bureau and China port

5 statistical yearbook with different classification, but no significant differences of the total amount.

There are 92 Chinese ports with cargo types-based transport volume statistic in this study. Raw data shown below. The regional transport volume statistics including liquid cargo, dry bulk, general cargo, container corresponding to tanker, bulk ship, general cargo ship, container ship, respectively. Among them, liquid cargo cover oil and gas; dry bulk cover ore, coal and building material; general cargo cover food, wood and

10 chemical material; container cover container and roro-car.

Table SI-5 shown in the last.

\section{Transport distance information}

Transport distance is the weight-based length along common routes of OGVs and CVs in the research domains of $12 \mathrm{Nm}$ and $200 \mathrm{Nm}$, respectively. Specifically, transport distances of OGVs were calculated as the

15 average of main international routes from main ports in a particular port cluster, as shown in Fig. SI-2(a), and then multiply by the fraction of regular routes to Korea, Japan, South China Sea and Pacific, respectively (see Table SI-6); transport distances of CVs were derived from transport distances between port clusters measured by AIS data and digital map. Some illustrations are given in Fig. SI-2(c) for readers to understand the AISbased digital map. We collected information more than 1000 regular routes, including their departure and

20 arrival ports. We classified departure and arrival ports into port clusters, and then used AIS data and digital map to calculate transport distances between port clusters (Fig. SI-2(b)).

Table SI-6 (a) Information of international regular routes from Chinese ports

\begin{tabular}{ccc}
\hline $\begin{array}{c}\text { Destination } \\
\text { country/region }\end{array}$ & $\begin{array}{c}\text { Number of regular } \\
\text { routes }\end{array}$ & Fraction \\
\hline America & 115 & $12 \%$ \\
Japan & 110 & $11 \%$ \\
Korea & 78 & $8 \%$ \\
Southeast Asia & 89 & $9 \%$ \\
Europe & 80 & $8 \%$ \\
Australia & 22 & $2 \%$ \\
\hline
\end{tabular}




\begin{tabular}{ccc}
\hline Mediterranean & 34 & $3 \%$ \\
Taiwan & 38 & $4 \%$ \\
Black Sea & 10 & $1 \%$ \\
Others & 422 & $42 \%$ \\
Total & 998 & $100 \%$ \\
\hline
\end{tabular}

Table SI-6(b) Port cluster-specific transport distance and its fraction

\begin{tabular}{cccc}
\hline Port cluster & Main route & $\begin{array}{c}\text { Transport } \\
\text { distance/Nm }\end{array}$ & $\begin{array}{c}\text { Fraction within } \\
\text { the port cluster }\end{array}$ \\
\hline \multirow{3}{*}{ PRD } & Korea & 1250 & $22 \%$ \\
& Japan & 1442 & $35 \%$ \\
& South China Sea & 1082 & $23 \%$ \\
Shandong & Pacific & 354 & $20 \%$ \\
\hline \multirow{3}{*}{ YRD } & Korea & 361 & $34 \%$ \\
& Japan & 847 & $35 \%$ \\
& South China Sea & 2130 & $21 \%$ \\
& Pacific & 550 & $10 \%$ \\
\hline \multirow{2}{*}{ Bohai } & Korea & 436 & $10 \%$ \\
& Japan & 888 & $15 \%$ \\
& South China Sea & 1858 & $40 \%$ \\
& Pacific & 516 & $35 \%$ \\
\hline Western Taiwan & Korea & 450 & $40 \%$ \\
Strait & Japan & 1423 & $15 \%$ \\
\hline Beibu Gulf & South China Sea & 813 & $15 \%$ \\
\hline & Pacific & 900 & $100 \%$ \\
\hline
\end{tabular}

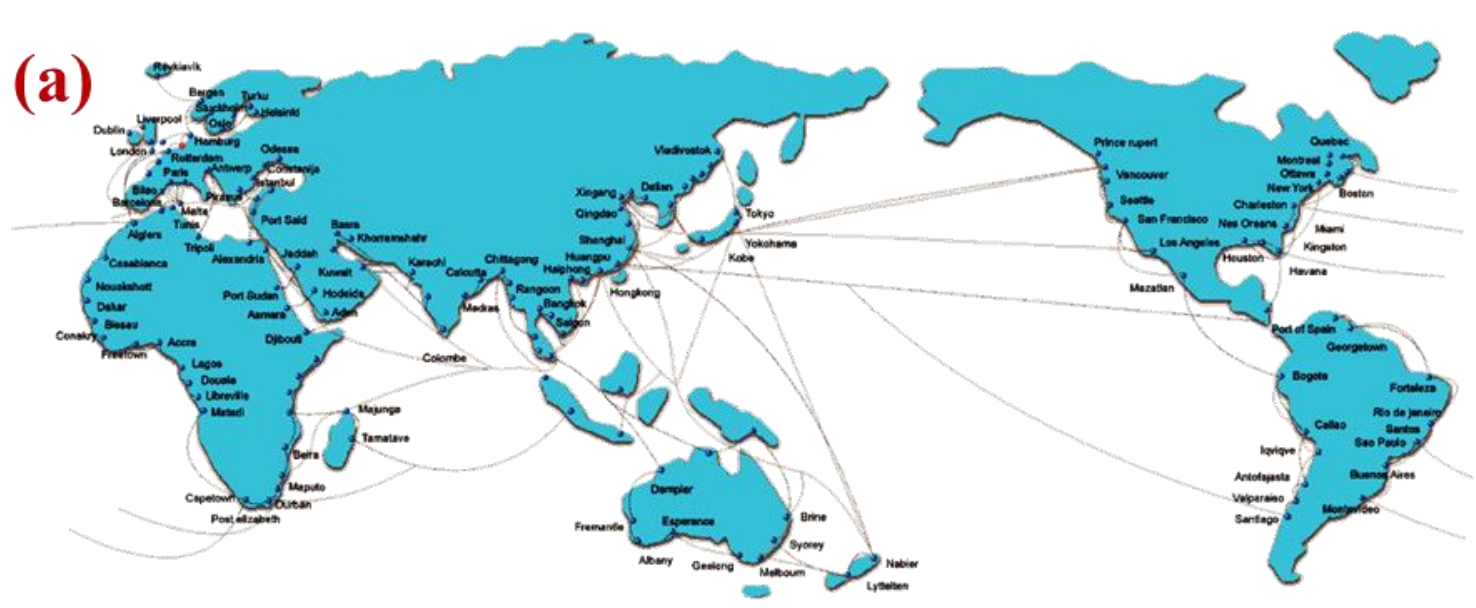



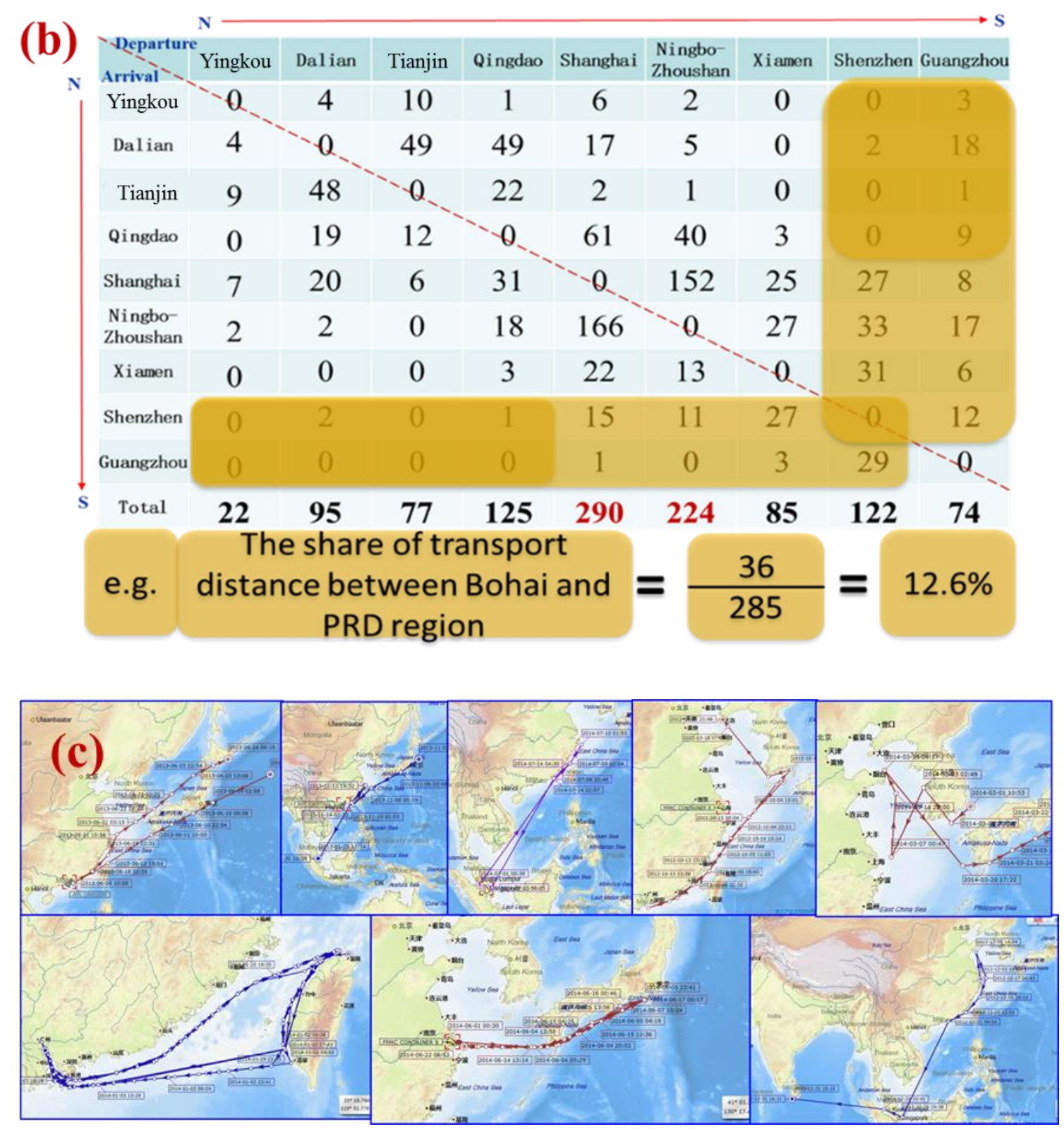

Fig. SI-2 (a) the major international routes in the world (the average transport distance of OGVs can be calculated by using the distance of those ocean-going routes by combining Table SI-6(a))

(b) samples of transport distances calculation process in determining the fraction within the port cluster (area with color were all routes for PRD; area with deep colors were the routes between Bohai and PRD, calculation process shown in this figure, with the same way, then can calculate the share of all routes, and the weight-based transport distance can be calculated by combining each routes' distances)

(c) the sample of calculation process on the share of transport distance among different region (transport distance can be calculated by using the AIS-based digital map with the distance measuring tool) 


\section{Uncertainties estimation}

Uncertainties of emissions factors and activity time for estimation were shown as following.

Table SI-7 Uncertainties of emissions factors for estimation

\begin{tabular}{ccccc}
\hline Pollutants & Categories & Distribution types & Mean & Confidence interval \\
\hline \multirow{2}{*}{$\mathrm{SO}_{2}$} & $\mathrm{HFO}(2.7 \%)$ & Weibull & 11.3 & $(-18.2 \%, 11.3 \%)$ \\
& $\mathrm{MDO}(0.5 \%)$ & Weibull & 1.4 & $(-74.8 \%, 107.4 \%)$ \\
\multirow{2}{*}{$\mathrm{NOx}$} & $\mathrm{SSD}$ & Gamma & 16.3 & $(-19.7 \%, 21.6 \%)$ \\
& $\mathrm{MSD}$ & Gamma & 13.8 & $(-9.6 \%, 10.4 \%)$ \\
& $\mathrm{HSD} *$ & Gamma & 11.5 & $(-26.0 \%, 29.2 \%)$ \\
$\mathrm{CO}$ & $\mathrm{OGVs} / \mathrm{CV} s$ & Gamma & 1.3 & $(-22.4 \%, 25.0 \%)$ \\
& $\mathrm{RVs}$ & Gamma & 1.3 & $(-22.4 \%, 25.0 \%)$ \\
$\mathrm{PM}_{10}$ & $\mathrm{HFO}(2.7 \%)$ & Gamma & 1.5 & $(-14.7 \%, 16.4 \%)$ \\
& $\mathrm{MDO}(0.5 \%)$ & Weibull & 0.4 & $(-42.4 \%, 34.6 \%)$ \\
$\mathrm{PM}_{2.5}$ & $\mathrm{HFO}(2.7 \%)$ & Weibull & 1.3 & $(-14.7 \%, 16.4 \%)$ \\
& $\mathrm{MDO}(0.5 \%)$ & Gamma & 0.4 & $(-42.4 \%, 34.6 \%)$ \\
$\mathrm{HC}^{*}$ & $\mathrm{OGV} / \mathrm{CVs}$ & Gamma & 0.5 & $(-32.7 \%, 36.5 \%)$ \\
$\mathrm{BC}^{*}$ & $\mathrm{RVs}$ & Weibull & 0.4 & $(-65.3 \%, 72.0 \%)$ \\
$\mathrm{OC}^{*}$ & All & Weibull & 0.3 & $(-97.7 \%, 126.5 \%)$ \\
\hline
\end{tabular}

*the value of $\mathrm{BC}$ and $\mathrm{OC}$ were the ratio of $\mathrm{BC} / \mathrm{PM}_{2.5}$ and $\mathrm{OC} / \mathrm{PM}_{2.5}$, respectively.

Table SI-8 Uncertainties of time-in-modes for estimation

\begin{tabular}{|c|c|c|c|c|c|c|}
\hline \multicolumn{2}{|c|}{ Ship types } & Modes & $\begin{array}{c}\text { Distribution } \\
\text { types }\end{array}$ & Mean/hours & $\begin{array}{l}\text { Lower bound } \\
\text { of uncertainty }\end{array}$ & $\begin{array}{l}\text { Upper bound } \\
\text { of uncertainty }\end{array}$ \\
\hline \multirow{8}{*}{ OGVs } & \multirow{2}{*}{ Tanker } & Maneuvering & Weibull & 4.3 & $-28 \%$ & $31 \%$ \\
\hline & & Hoteling & Weibull & 25.3 & $-17 \%$ & $16 \%$ \\
\hline & \multirow{2}{*}{ Cargo ship } & Maneuvering & Gamma & 3.4 & $-15.1 \%$ & $20.9 \%$ \\
\hline & & Hoteling & Weibull & 15.8 & $-9.8 \%$ & $6.0 \%$ \\
\hline & \multirow{2}{*}{$\begin{array}{l}\text { Container } \\
\text { ship }\end{array}$} & Maneuvering & Weibull & 3.7 & $-11 \%$ & $10 \%$ \\
\hline & & Hoteling & Weibull & 22.2 & $-16 \%$ & $17 \%$ \\
\hline & \multirow{2}{*}{ Others } & Maneuvering & Weibull & 1.1 & $-62.1 \%$ & $96.5 \%$ \\
\hline & & Hoteling & Gamma & 17.2 & $-50.0 \%$ & $60.1 \%$ \\
\hline \multirow{8}{*}{$\mathrm{CVs}$} & \multirow{2}{*}{ Tanker } & Maneuvering & Gamma & 2.3 & $-35.9 \%$ & $53.8 \%$ \\
\hline & & Hoteling & Normal & 23.5 & $-15.3 \%$ & $19.0 \%$ \\
\hline & \multirow{2}{*}{ Cargo ship } & Maneuvering & Gamma & 3.2 & $-84.3 \%$ & $160.4 \%$ \\
\hline & & Hoteling & Gamma & 16.8 & $-17.5 \%$ & $18.7 \%$ \\
\hline & \multirow{2}{*}{$\begin{array}{l}\text { Container } \\
\text { ship }\end{array}$} & Maneuvering & Normal & 3.9 & $-53.0 \%$ & $46.7 \%$ \\
\hline & & Hoteling & Weibull & 19.1 & $-29.9 \%$ & $29.4 \%$ \\
\hline & \multirow{2}{*}{ Others } & Maneuvering & Gamma & 2.7 & $-84.8 \%$ & $164.9 \%$ \\
\hline & & Hoteling & Gamma & 17.7 & $-84.2 \%$ & $172.6 \%$ \\
\hline
\end{tabular}




\section{AIS data information}

According to the most advanced study (Liu et al., 2016), the introduction of automatic vessel position reporting systems has significantly reduced the uncertainty concerning ship activities and their geographical distribution. However, using shipping activity data for research remains a challenging task (Dalsoren et al.,

5 2009; Liu et al., 2016). Different with Liu's study, this study established a model for ship activity data calculation by using a continuously trajectories AIS dataset but not comprehensive in China Sea. Here I given a comparison of AIS data (Dalsoren et al., 2009; Liu et al., 2016) to demonstrate that the representativeness of our ship information dataset in China Sea is acceptable (table SI-9).

Table SI-9 ship information statistics in China and in the other studies

\begin{tabular}{llllll}
\hline Study area & Year & $\begin{array}{l}\text { Area } \\
\text { Million } \mathrm{km}^{2}\end{array}$ & $\begin{array}{l}\text { Archived AIS } \\
\text { messages }\end{array}$ & $\begin{array}{l}\text { Number of ship } \\
\text { with AIS }\end{array}$ & $\begin{array}{l}\text { Number of ship } \\
\text { information }\end{array}$ \\
\hline China Sea & 2013 & 3.0 & $3.5 \mathrm{E}+08$ & 700 & 12,600 \\
East Asia & 2013 & 4.2 & $2.0 \mathrm{E}+09$ & 18,324 & 18,324 \\
Baltic sea & 2009 & 0.4 & $2.6 \mathrm{E}+08$ & 11,606 & 11,606 \\
\hline
\end{tabular}

10

The AIS was introduced by the IMO international Convention for the Safety of Life at Sea.

Which include shore-based and satellite-based data. The shore-based data is featured by high temporal resolution (every 30 seconds), but only covers ships less than 50 nautical miles from the shore. For the areas beyond 50 nautical miles, satellite-based data in 2-h interval was used.
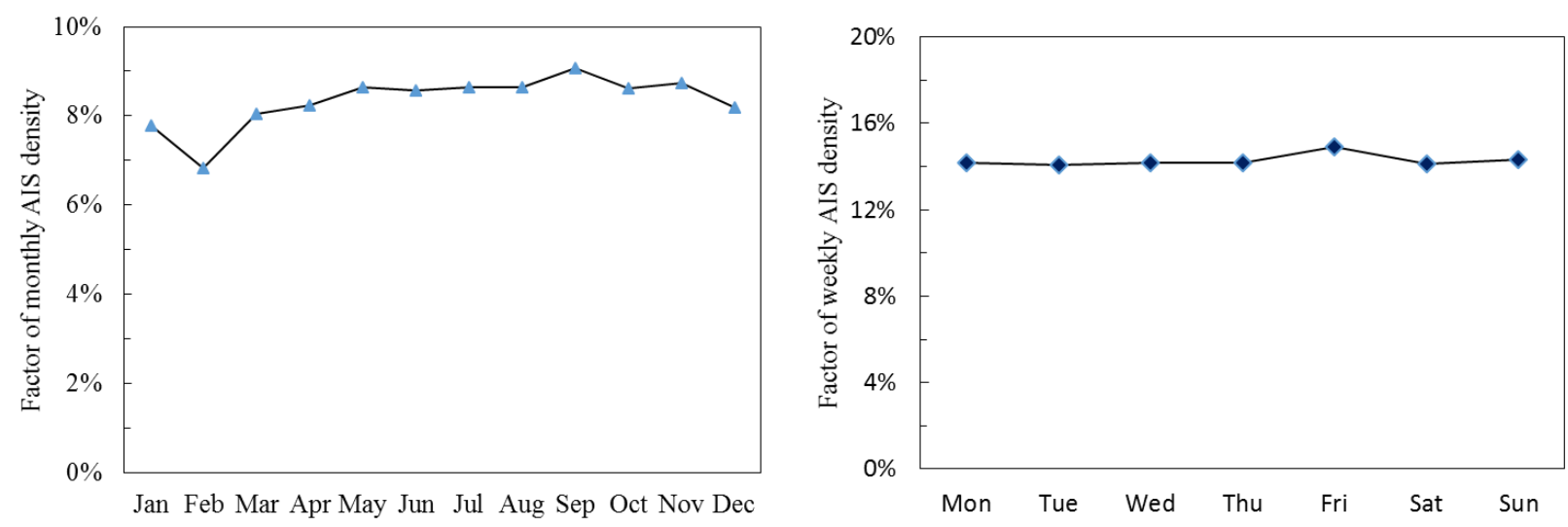

Fig. SI-3 the monthly and weekly variation of ship fuel consumption by using AIS dot-density in 2013 

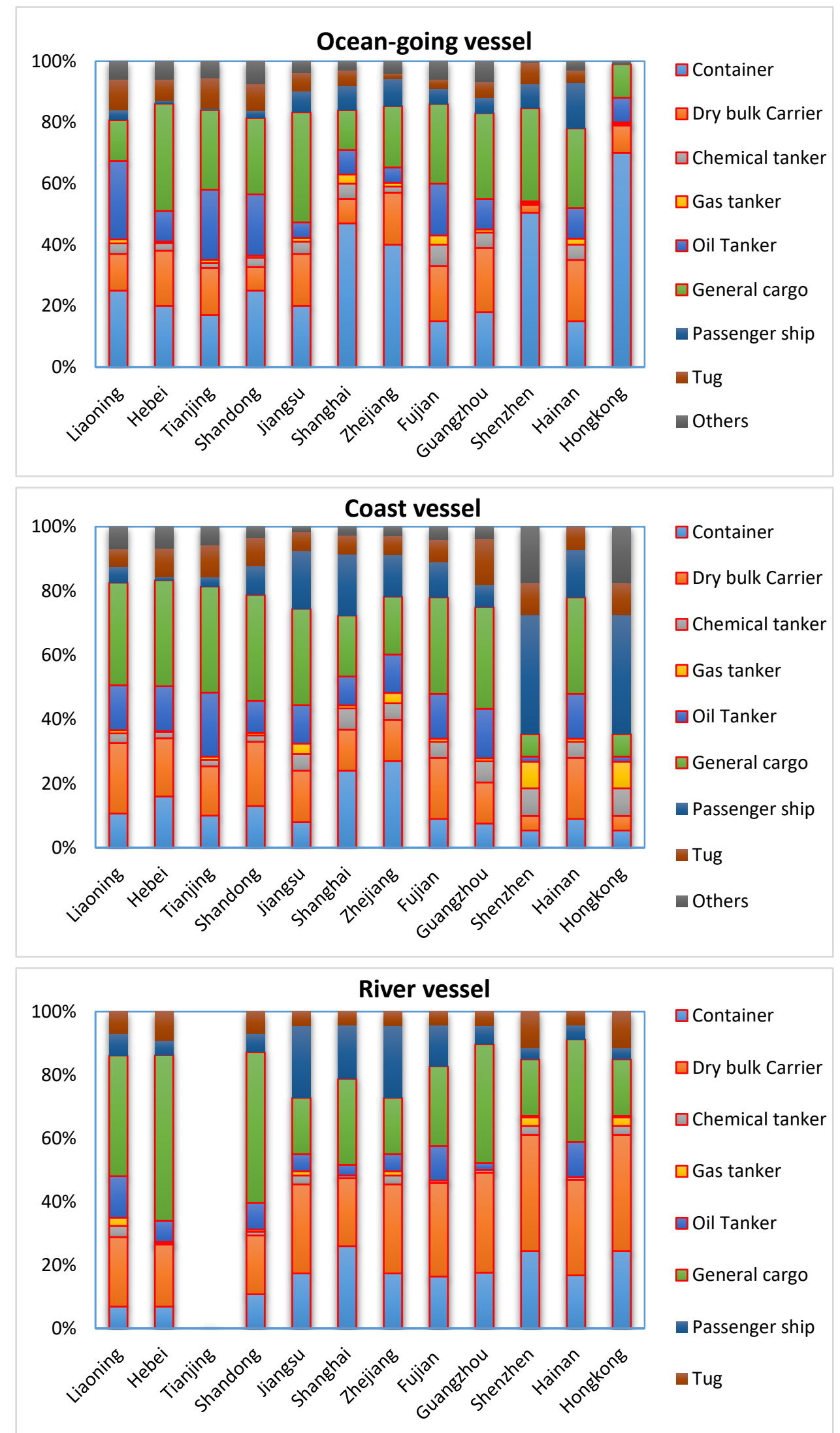

Fig. SI-4 Summary of the stock of ship types navigated in different regions for OGVs, CVs and RVs 


\section{Fuel consumption information}

For fuel consumption rate (Kg tce/KtNm), the value of different ship types can be obtained from CCTD in 20102015, but the value of OGVs are not within the typical ranges of corresponding ship type from IMO report (IMO, 2015), as detailed in Fig. SI-6, that maybe caused by the statistics of the international trade in ocean going cargo 5 companies. So the median value of the range provided by IMO were used to estimate in cargo-based approach. For the fuel consumption rate for RVs, which refer to the value from CCTD, 5.2 tce/10kt, that why we do not need the transport distance of RVs.

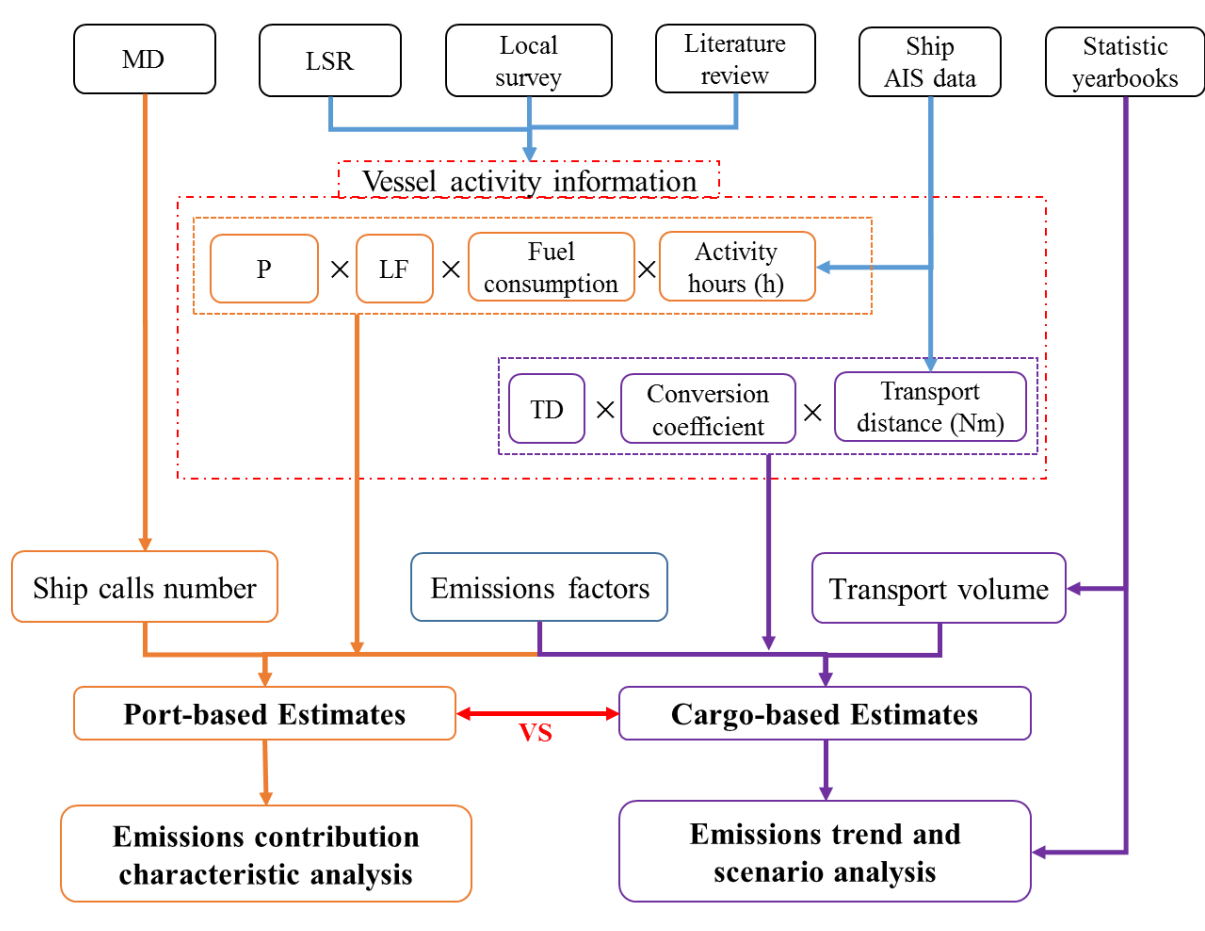

Fig. SI-5 Data sources and flowchart used for emissions estimates in this study 


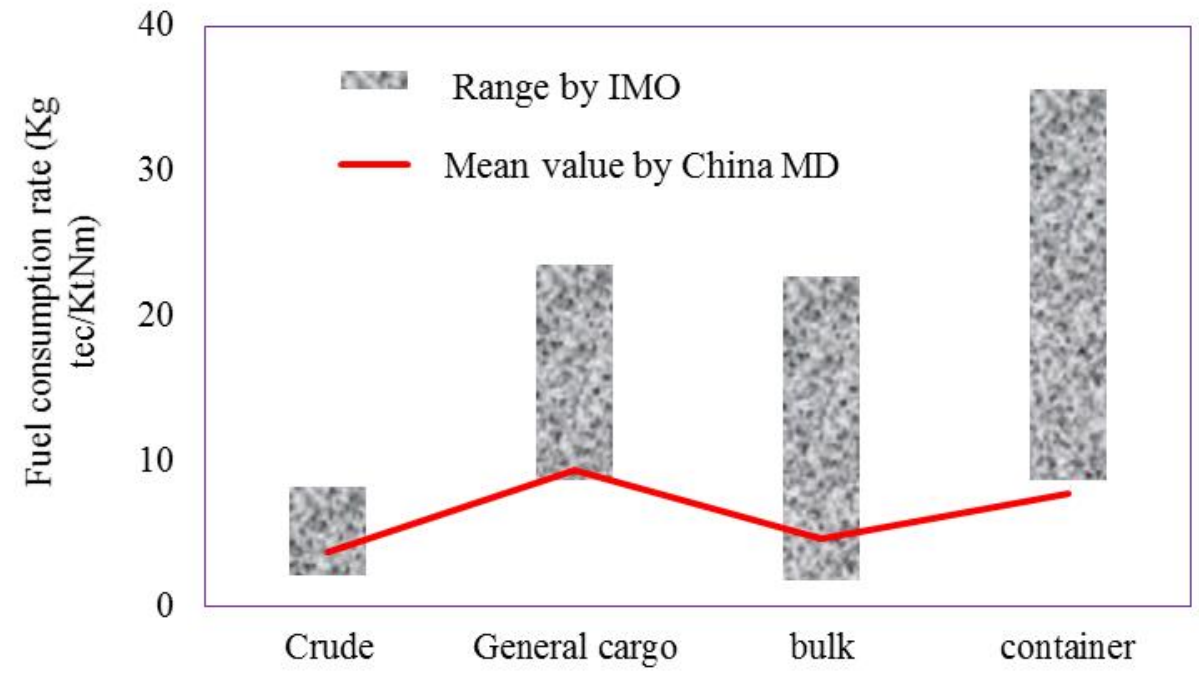

Fig. SI-6 Range of fuel consumption rate used in this study

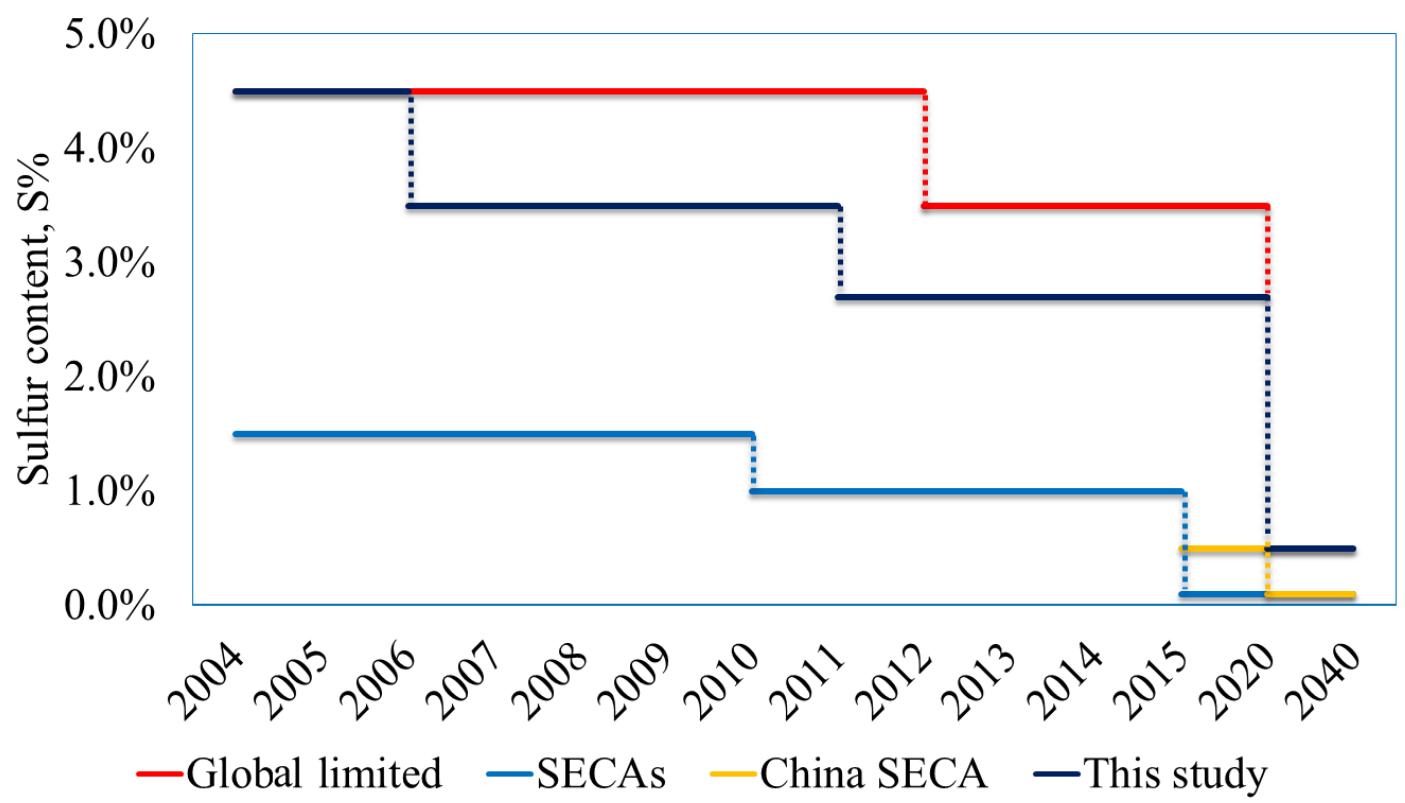

Fig. SI-7 The sulfur content of HFO in this study 


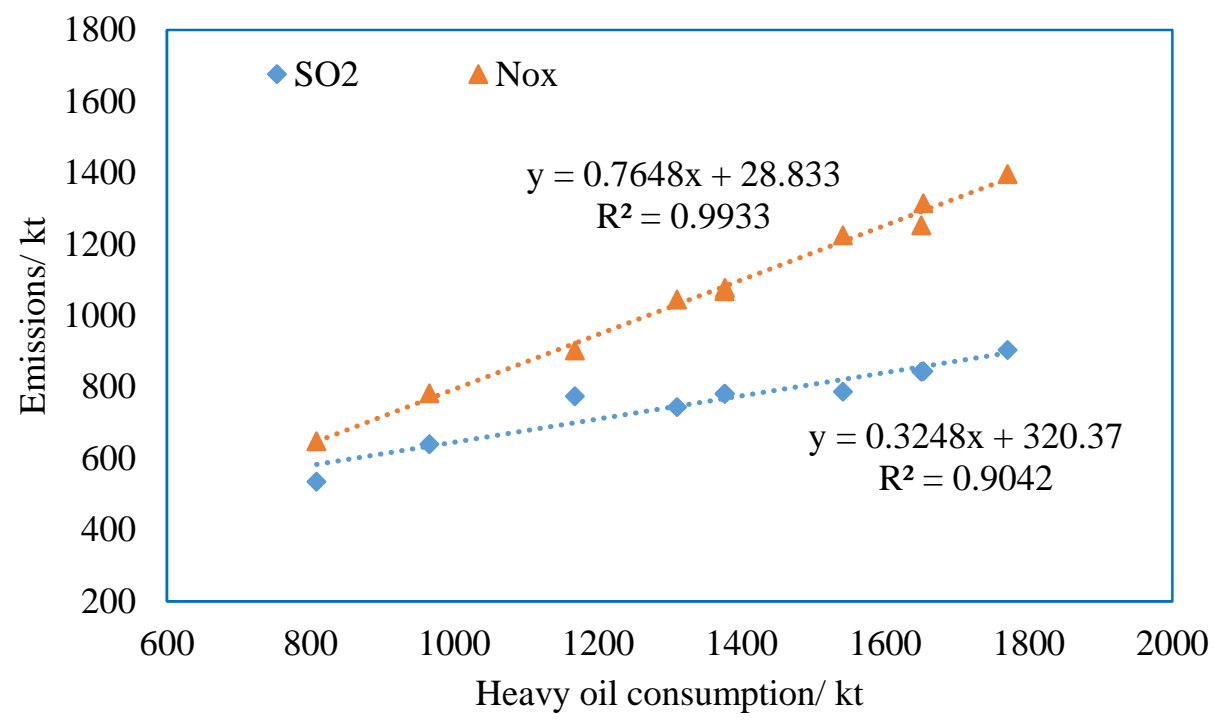

Fig. SI-8 Relationship between fuel consumption and ship emissions from 2004 to 2013

\section{Ship engine and emission factor}

For ship engine, the slow speed diesel engine were dominated by the international brands, e.g. MAN SE (from

5 Germany, share $78 \%$ stock of market), Wärtsilä (from Dutch, share 21\% stock of market), this is to say that the emission factor for SSD of ship engine used in China can refer to the international value. However, the medium speed diesel engine $(430 \mathrm{~kW}<\mathrm{P}<14,940 \mathrm{~kW})$ were dominated by the local diesel engine brands, e.g. Zichai, Weichai, Guangchai, Zhongcedongli. Which covered more than $80 \%$ of the total population of MSD, mainly used for the main engine and auxiliary engine of river ship and fishing ship, therefore, the emission factor of

10 river vessel refers to the result measured by the local studies (Zhang et al., 2015).

Statistics for main engine speed by vessel type and gross tonnage has been determined from the available database. The RPM value, available for approximately $68 \%$ of the main engines, has been used to determine if the engine is high speed diesel (HSD), medium (MSD) or slow (SSD) speed. Consistent with earlier studies (Entec, 2002, 2010; Ng et al., 2012), HSD engines were defined as engines with an RPM>1000, MSD engines were defined as engines with an RPM $\leq 1000$ and RPM $>300$, and SSD engines were defined as engines with an $\mathrm{RPM} \leq 300$. The main engine types for three vessel size ranges were determined by identified the number of vessels with HSD, MSD and SSD. For the classification of different operation modes were shown in table SI3.

The $\mathrm{SO}_{2}$ emission depend on engine type and sulphur content of fuel oil. Due to the value of sulfur content 20 statistics by China Marine Bunker (Fan et al., 2016) were higher than global averages reported by the IMO 
Maritime Environment Protection Committee (MEPC, 67th), so, sulfur content for HFO and MDO were set as $2.7 \%$ and $0.5 \%$ in this study, and a sulphur content corresponding to the sulphur limit required in the ECA is assumed in both main engines, auxiliary engines and boilers, meanwhile, the key issue of $\mathrm{SO}_{2}$ generation rate from the sulphur in fuel oil were solved by literature review, set as $83 \%, 90 \%$ and $94 \%$ for HSD, MSD,

5 HSD, respectively (USEPA ship report; Liu et al., 2016; Fan et al., 2016). For NOx emission, as shown in table SI-10, MARPOL Annex VI given a progressive reductions in NOx emissions from marine diesel engine, with more stringent controls being a "Tier II" emission limit required for those marine diesel engines installed on or after 1 January 2011; then with the most stringent controls being "Tier III" emission limit for marine diesel engines installed on or after 1 January 2016. Marine diesel engines installed on or after 1 January 1990

10 but prior to 1 January 2000 are also required to comply with "Tier I" emission limits, if an approved method for that engine has been certified by an Administration. On the other hand, fuel type and quality sulphur content as a major factor influencing the emissions of $\mathrm{PM}, \mathrm{HC}$ and $\mathrm{CO}$, and engine type also have effects on PM. As detail shown in table SI-11.

$$
\mathrm{SO}_{2} \text { Emission }=\text { Fuel consumption } \times 2 \times \mathrm{S} \% \times \mathrm{R}
$$

Table SI-10 NOx emission factors used in this study (unit: g/kg Fuel)

\begin{tabular}{|c|c|c|c|c|}
\hline Fuel type & Engine type & Emission Stander & Model year & Emission Factor \\
\hline \multirow{6}{*}{$\begin{array}{l}\text { HFO }(2.7 \% \text { sulfur } \\
\text { content })\end{array}$} & SSD & \multirow{2}{*}{ Tier $0^{[1]}$} & $\leq 1999$ & 79.7 \\
\hline & MSD & & $\leq 1999$ & 61.7 \\
\hline & SSD & \multirow{2}{*}{ Tier1 } & $2000-2010$ & 74.9 \\
\hline & MSD & & $2000-2010$ & 57.3 \\
\hline & SSD & \multirow{2}{*}{ Tier2 } & 2011-2015 & 67.4 \\
\hline & SSD & & 2011-2015 & 49.3 \\
\hline \multirow{7}{*}{$\begin{array}{c}\text { MDO } \\
(0.5 \% \text { sulfur } \\
\text { content })\end{array}$} & SSD & \multirow{2}{*}{ Tier $0^{\mathrm{a}}$} & $\leq 1999$ & 78.3 \\
\hline & MSD & & $\leq 1999$ & 60.8 \\
\hline & SSD & \multirow{2}{*}{ Tier1 } & $2000-2010$ & 73.7 \\
\hline & MSD & & $2000-2010$ & 56.2 \\
\hline & SSD & \multirow{2}{*}{ Tier2 } & 2011-2015 & 66.4 \\
\hline & SSD & & 2011-2015 & 48.4 \\
\hline & HSD & Before Tier $3^{b}$ & All & 46.1 \\
\hline HFO/MDO & Boiler $^{[3]}$ & All & All & 15.7 \\
\hline \multirow{3}{*}{$\begin{array}{l}\text { LNG or other } \\
\text { clean energy }\end{array}$} & SSD & \multirow{3}{*}{ Tier $3^{b}$} & $>2016$ & 14.8 \\
\hline & MSD & & $>2016$ & 11.3 \\
\hline & HSD & & $>2016$ & 9.2 \\
\hline
\end{tabular}


aMO Tier 0 refers to all ships constructed prior to January 1, 2000 which did not have an IMO Tier requirement at the time of construction.

${ }^{\text {b} T i e r ~} 3$ means conduct NOx emission control measures, e.g. LNG-fueled engine, Emission gas recycle, Selective catalytic reduction of NOx (SCR), that means the control policies of Emission Control Area (ECA). ${ }^{[3]}$ Which means Boiler engine.

Table SI-11 Emission factors used in ship emission estimates (unit: g/kg Fuel)

\begin{tabular}{ccccccccccc}
\hline $\begin{array}{c}\text { Activity } \\
\text { Type }\end{array}$ & Engine Type & Fuel Type & $\begin{array}{c}\text { Sulfur } \\
\text { content }\end{array}$ & $\mathbf{P M}_{\mathbf{1 0}}$ & $\mathbf{P M}_{2.5}$ & $\mathbf{H C}$ & $\mathbf{C O}$ & BC $^{\mathbf{f}}$ & OC $^{\mathbf{f}}$ \\
\hline $\mathrm{OGVs}_{\mathrm{CV} s} \mathrm{a}$ & $\mathrm{ME}^{\mathrm{c}}$ & $\mathrm{SSD}$ & $\mathrm{HFO}$ & $2.7 \%$ & 6.1 & 5.7 & 2.6 & 6.1 & 0.36 & 0.23 \\
$\mathrm{OGVs} / \mathrm{CVs}$ & $\mathrm{ME}^{\mathrm{c}}$ & $\mathrm{SSD}$ & $\mathrm{MDO}$ & $0.5 \%$ & 2.2 & 1.7 & 2.6 & 6.1 & 0.36 & 0.23 \\
$\mathrm{OGVs} / \mathrm{CVs}$ & $\mathrm{ME}^{\mathrm{c}}$ & $\mathrm{MSD}$ & $\mathrm{HFO}$ & $2.7 \%$ & 6.1 & 5.7 & 2.2 & 4.8 & 0.16 & 0.18 \\
$\mathrm{OGVs} / \mathrm{CVs}$ & $\mathrm{ME}^{\mathrm{c}}$ & $\mathrm{MSD}$ & $\mathrm{MDO}$ & $0.5 \%$ & 2.2 & 1.7 & 2.2 & 4.8 & 0.16 & 0.18 \\
$\mathrm{OGVs} / \mathrm{CVs}$ & $\mathrm{AE}^{\mathrm{d}}$ & $\mathrm{HSD}$ & $\mathrm{HFO}$ & $2.7 \%$ & 6.1 & 5.7 & 1.7 & 4.8 & 0.16 & 0.18 \\
$\mathrm{OGVs} / \mathrm{CVs}$ & $\mathrm{AE}^{\mathrm{d}}$ & $\mathrm{HSD}$ & $\mathrm{MDO}$ & $0.5 \%$ & 2.2 & 2.2 & 1.7 & 4.8 & 0.16 & 0.18 \\
$\mathrm{OGVs} / \mathrm{CVs}$ & $\mathrm{BE}^{\mathrm{e}}$ & $\mathrm{HSD}$ & $\mathrm{MDO}$ & $0.5 \%$ & 1.3 & 1.0 & 0.4 & 0.9 & 0.58 & 0.12 \\
$\mathrm{RVs}$ & $\mathrm{ME}^{\mathrm{c}}$ & $\mathrm{HSD}$ & $\mathrm{MDO}$ & $0.5 \%$ & 1.7 & 1.7 & 1.7 & 6.0 & 0.58 & 0.12 \\
\hline
\end{tabular}

a, bOGVs, CVs and RVs mean Ocean-going vessels, Coast vessels and River vessels, respectively.

c, d, e ME, AE and BE mean main engine, auxiliary engine and boiler engine, respectively.

f the value of $\mathrm{BC}$ and $\mathrm{OC}$ were the ratio of $\mathrm{BC} / \mathrm{PM}_{2.5}$ and $\mathrm{OC} / \mathrm{PM}_{2.5}$, respectively. Refer to zhang et al., 2015.

10

Besides, the relationship of ship types to engine types and fuel types were the essential in emission estimation, shown in table SI-12. On the other hand, fuel type and sulfur content are the most important specification in ship fuels. According to the previous research (Ng et al., 2012; Fan et al, 2016; Liu et al., 2016), for three engine types in vessel types with the main fuel types has been identified. On the other hand, no specific ship emission

15 control regulation was assigned in this study domain in 2013 except a two-year industry-led voluntary fuel switch initiative (the Fair Winds Charter, $\mathrm{S} \% \leq 0.5 \%$ ) in Hong Kong in January 2011. Therefore, sulfur content for $\mathrm{HFO}$ and $\mathrm{MDO}$ were set as $2.7 \%$ and $0.5 \%$ (set value refer the domestic vessels ranges from $0.2 \%$ to $2.0 \%$, provided by China Marine Bunker, CMB) (Fan et al., 2016). 
Table SI-12 Relationship of ship types to engine types and fuel types

\begin{tabular}{ccccccccc}
\hline & & \multicolumn{3}{c}{ Engine Types } & \multicolumn{3}{c}{ Fuel Types } \\
\cline { 3 - 8 } & Ship types & DWT $\leq 5000 \mathrm{GT}$ & $\begin{array}{c}5000<\mathrm{DWT}< \\
25000\end{array}$ & $\geq 25000 \mathrm{GT}$ & ME & AE & BE \\
\hline $\begin{array}{c}\text { OGVs } \\
\text { and }\end{array}$ & $\begin{array}{c}\text { Dry Bulk } \\
\text { CVs }\end{array}$ & Carrier & MSD & MSD & SSD & HFO & HFO & MDO \\
& Container & MSD & MSD & SSD & HFO & HFO & MDO \\
& General cargo & MSD & SSD & SSD & HFO & HFO & MDO \\
& ship & MSD & SSD & SSD & HFO & HFO & MDO \\
& Tanker & Others & MSD & MSD & SSD & MDO & MDO & MDO \\
& & HSD & & & MDO & \\
\hline
\end{tabular}

*SSD, MSD, HSD mean Slow speed diesel engine, Medium speed diesel engine, High speed diesel engine, respectively. HFO and MDO mean Marine heavy oil and Marine diesel oil.

Table SI-13 Low load adjustment multipliers for emission factors

\begin{tabular}{cccccc}
\hline $\mathbf{L F}$ & $\mathbf{S O}_{2}$ & NOx & CO & PM & HC \\
\hline 0.01 & 1.00 & 11.47 & 19.32 & 19.17 & 59.28 \\
0.02 & 1.00 & 4.63 & 9.68 & 7.29 & 21.18 \\
0.03 & 1.00 & 2.92 & 6.46 & 4.33 & 11.68 \\
0.04 & 1.00 & 2.21 & 4.86 & 3.09 & 7.71 \\
0.05 & 1.00 & 1.83 & 3.89 & 2.44 & 5.61 \\
0.06 & 1.00 & 1.6 & 3.25 & 2.04 & 4.35 \\
0.07 & 1.00 & 1.45 & 2.79 & 1.79 & 3.52 \\
0.08 & 1.00 & 1.35 & 2.45 & 1.61 & 2.95 \\
0.09 & 1.00 & 1.27 & 2.18 & 1.48 & 2.52 \\
0.1 & 1.00 & 1.22 & 1.96 & 1.38 & 2.2 \\
0.11 & 1.00 & 1.17 & 1.79 & 1.3 & 1.96 \\
0.12 & 1.00 & 1.14 & 1.64 & 1.24 & 1.76 \\
0.13 & 1.00 & 1.11 & 1.52 & 1.19 & 1.6 \\
0.14 & 1.00 & 1.08 & 1.41 & 1.15 & 1.47 \\
0.15 & 1.00 & 1.06 & 1.32 & 1.11 & 1.36 \\
0.16 & 1.00 & 1.05 & 1.24 & 1.08 & 1.26 \\
0.17 & 1.00 & 1.03 & 1.17 & 1.06 & 1.18 \\
0.18 & 1.00 & 1.02 & 1.11 & 1.04 & 1.11 \\
0.19 & 1.00 & 1.01 & 1.05 & 1.02 & 1.05 \\
0.20 & 1.00 & 1.00 & 1.00 & 1.00 & 1.00 \\
\hline
\end{tabular}




\section{Emissions intensity calculation}

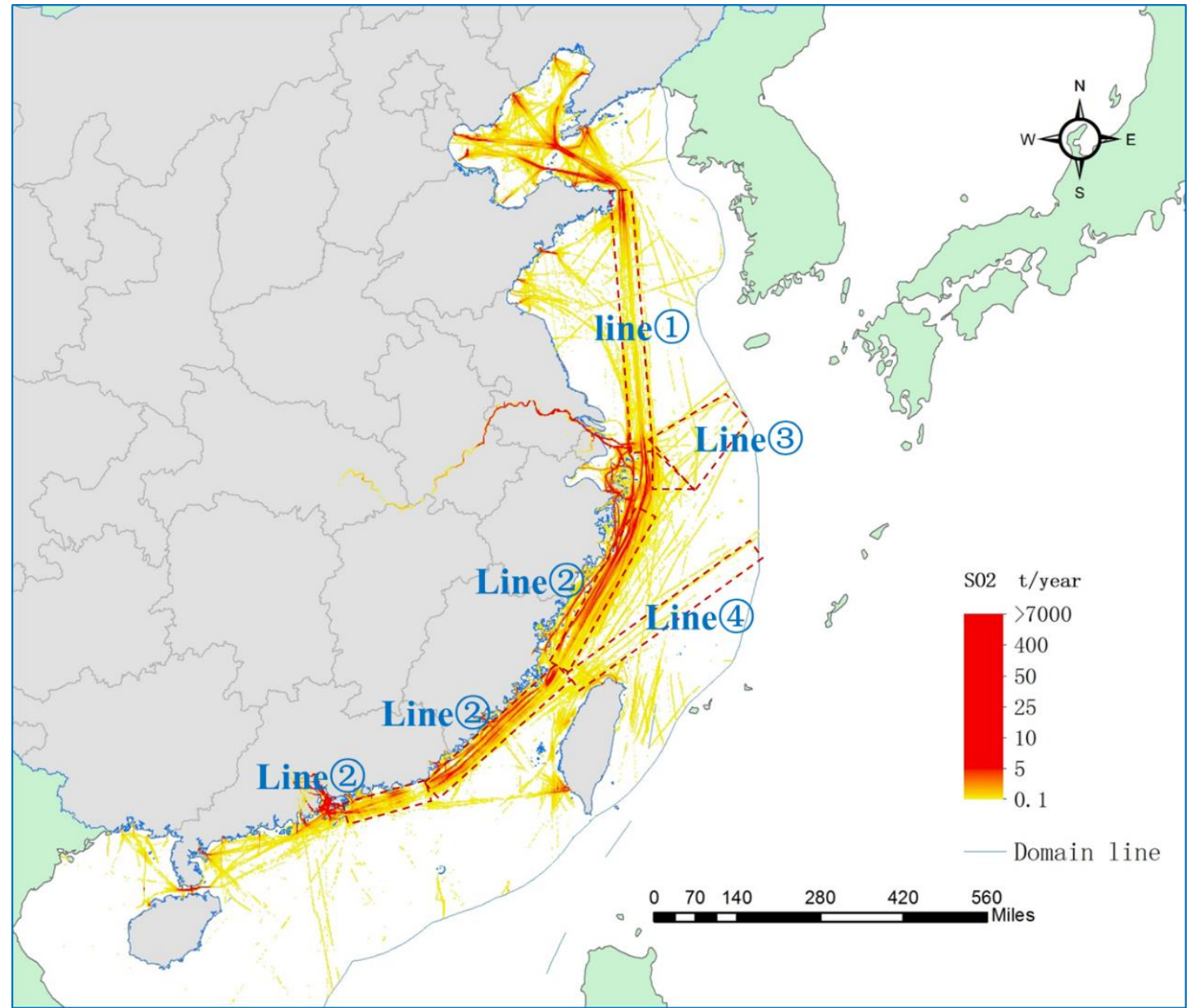

Fig. SI-9 Spatial allocation of typical navigating lines in Emission intensities calculation

\section{Emission trends analysis}

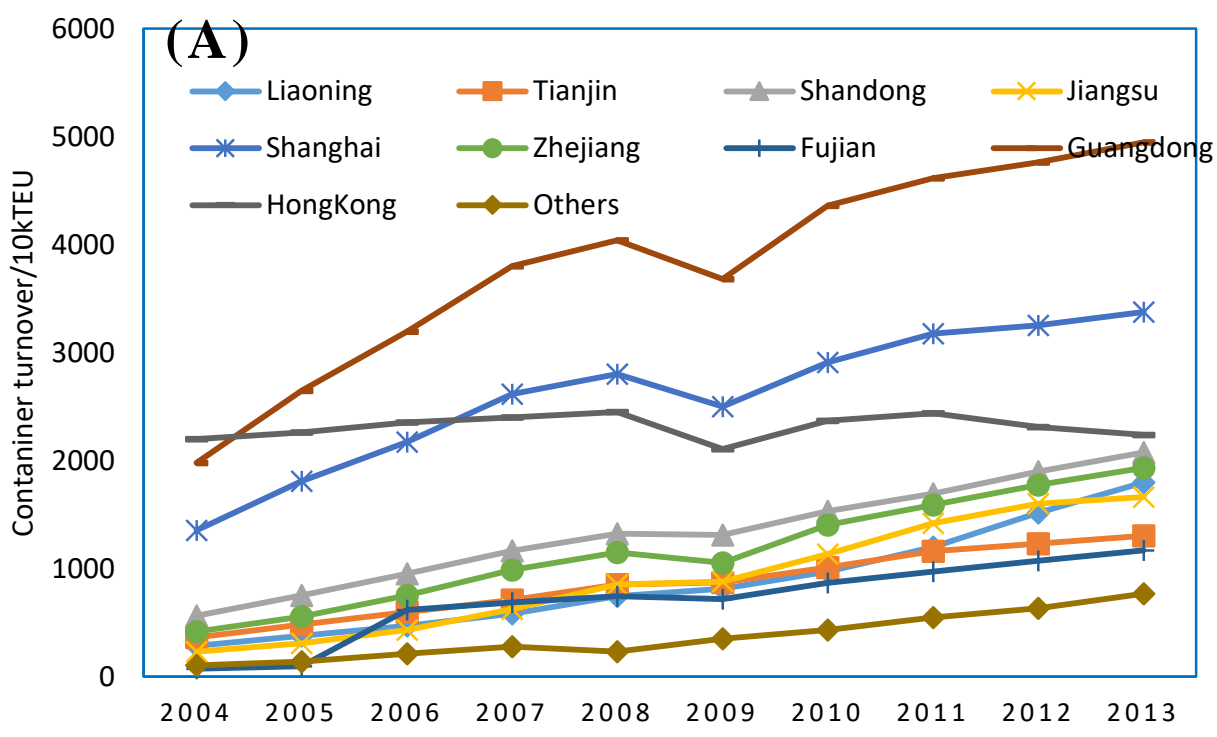




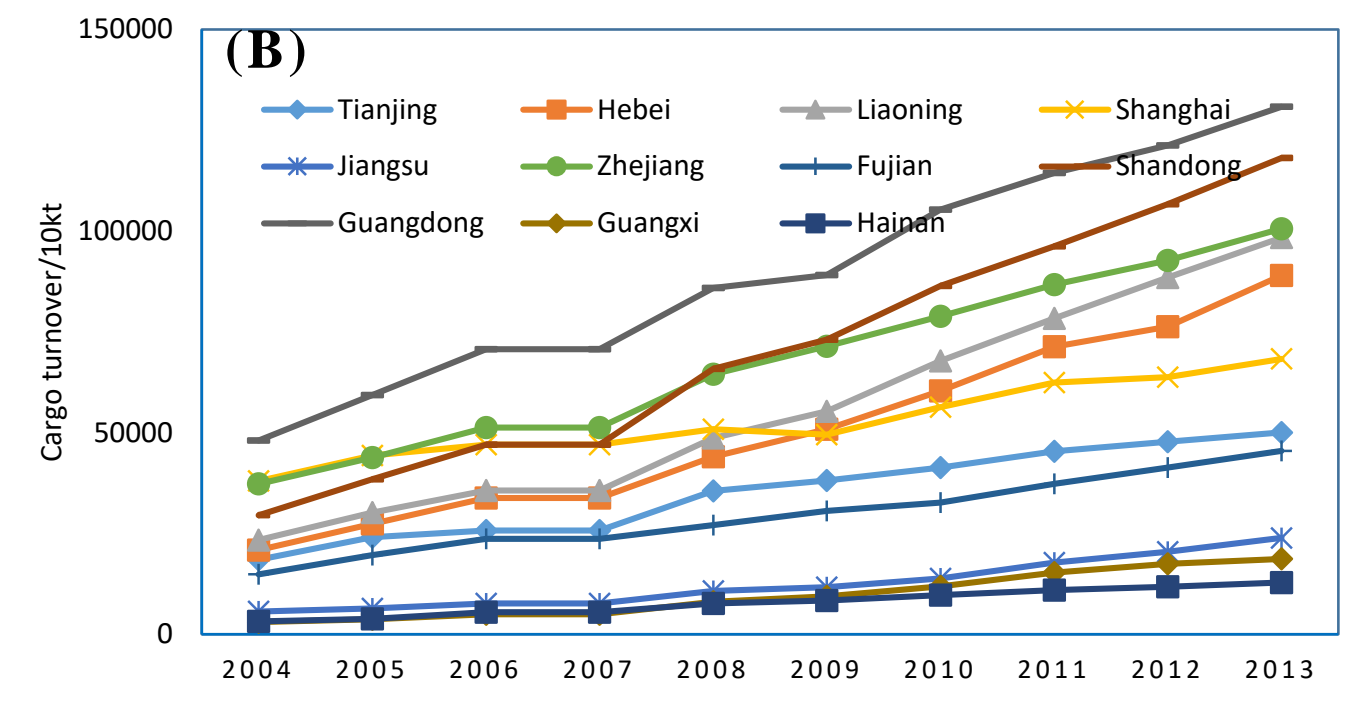

Fig. SI-10 Trends of container turnover (a) and cargo turnover (b) from coast ports in different provinces

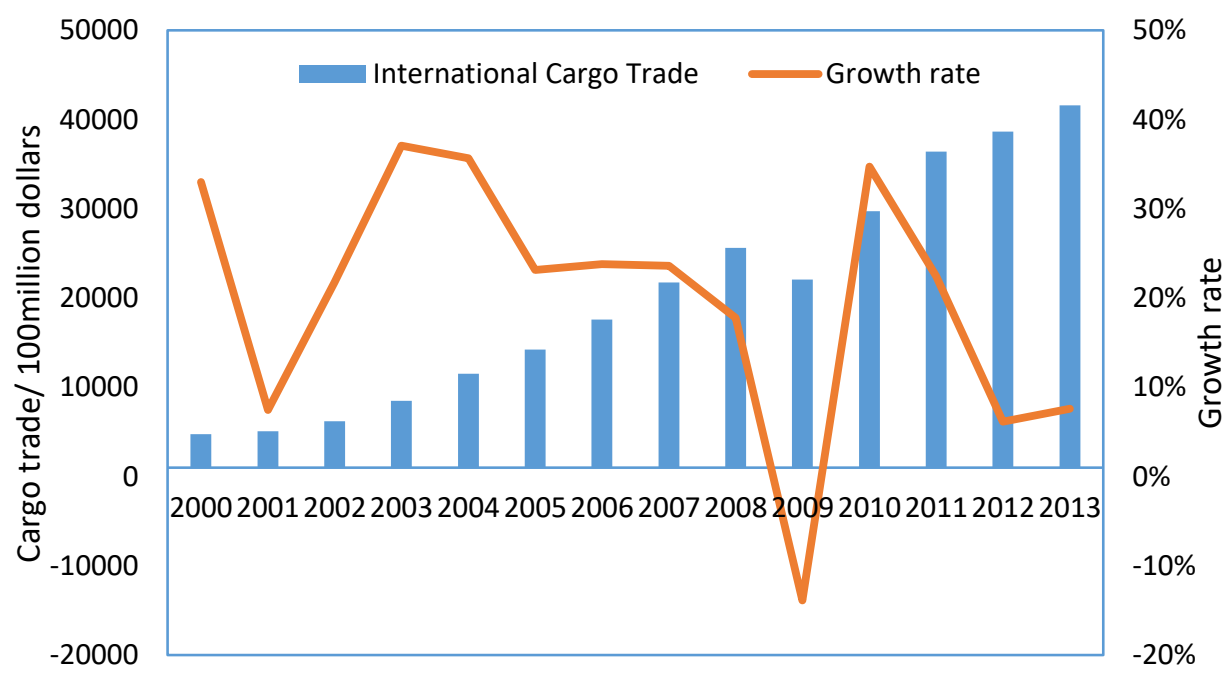

Fig. SI-11 Trends of international cargo trade and growth rate in China

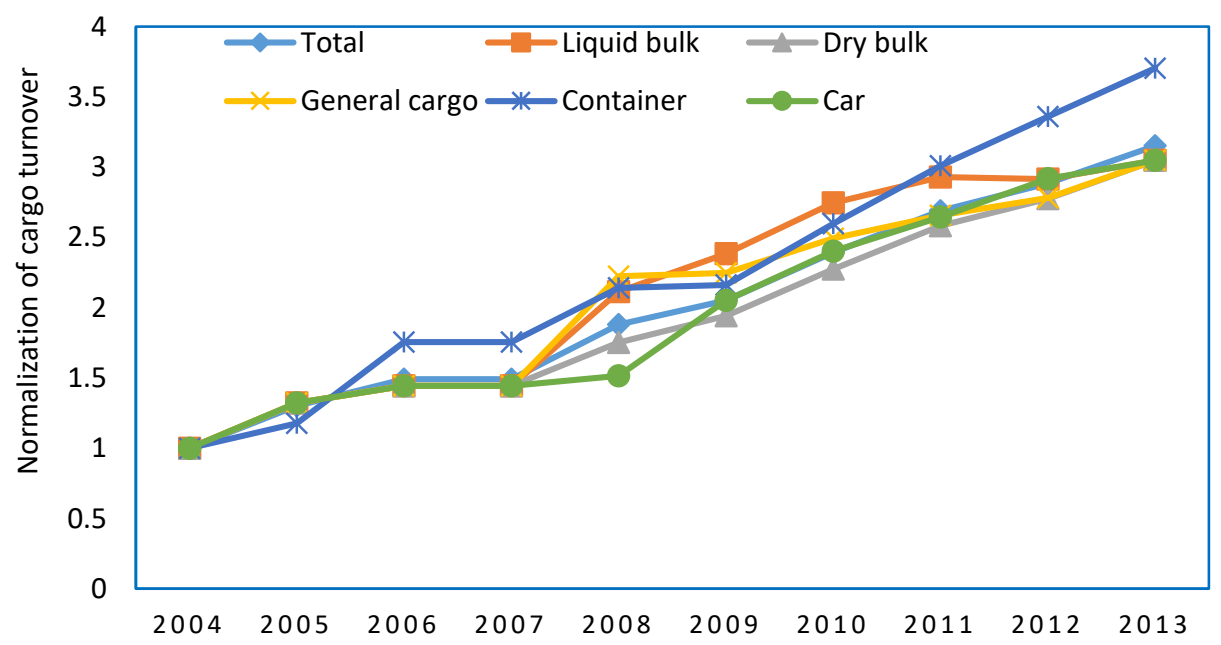

Fig. SI-12 Trends of cargo turnover with different cargo types in China from 2004 to 2013 
Table SI-5(a) Raw data of transport volume for cargo-based approach in 2013

\begin{tabular}{|c|c|c|c|c|c|c|c|c|c|c|}
\hline \multirow{2}{*}{\multicolumn{2}{|c|}{ Year: 2013}} & \multirow[b]{3}{*}{ Ports } & \multicolumn{6}{|c|}{ Cargo transport (10Kt) } & \multirow{3}{*}{$\begin{array}{l}\text { Ocean-going } \\
\text { Cargo } \\
\text { transport } \\
(10 \mathrm{Kt})\end{array}$} & \multirow{3}{*}{$\begin{array}{c}\text { Container } \\
\text { transport } \\
\text { (10000TEU) }\end{array}$} \\
\hline & & & & \multicolumn{3}{|c|}{ Dry bulk } & \multirow{2}{*}{$\begin{array}{c}\text { Liquid } \\
\text { cargo } \\
\text { Oil and } \\
\text { Gas }\end{array}$} & \multirow{2}{*}{$\begin{array}{c}\text { General Cargo } \\
\text { Others } \\
\text { (Chemical, } \\
\text { food, wood, } \\
\text { etc.) }\end{array}$} & & \\
\hline $\begin{array}{c}\text { Port } \\
\text { clusters }\end{array}$ & Province & & Total & Ore & $\begin{array}{l}\text { Building } \\
\text { materials }\end{array}$ & Coal & & & & \\
\hline \multirow{14}{*}{ 1.Bohai } & Heilongjiang & Heilongjiang & 1245 & 656 & 22 & 55 & 5 & 508 & 0 & 0 \\
\hline & Ji’ning & Ji`ning & 13379 & 0 & 35 & 2 & 1465 & 11878 & 0 & 0 \\
\hline & \multirow{4}{*}{ Hebei } & Total & 39594 & 10284 & 0 & 28084 & 1160 & 0 & 7008 & 67 \\
\hline & & Huanghua & 8310 & 1360 & 0 & 6847 & 92 & 0 & 1471 & 12 \\
\hline & & Qinghuaidao & 12681 & 308 & 0 & 11914 & 440 & 0 & 2245 & 19 \\
\hline & & Tangshan & 18603 & 8616 & 0 & 9323 & 628 & 0 & 3293 & 36 \\
\hline & Tianjin & Tianjin & 25040 & 5409 & 300 & 4481 & 2654 & 11500 & 13372 & 651 \\
\hline & \multirow{7}{*}{ Liaoning } & Total & 49217 & 11072 & 7774 & 3656 & 12071 & 13745 & 9891 & 899 \\
\hline & & Dalian & 20381 & 815 & 3900 & 1400 & 5300 & 8450 & 5884 & 501 \\
\hline & & Yingkou & 16038 & 5122 & 2241 & 1281 & 5282 & 1848 & 3111 & 265 \\
\hline & & Jingzhou & 4266 & 600 & 484 & 975 & 0 & 2160 & 426 & 48 \\
\hline & & Dandong & 6025 & 4100 & 1150 & 0 & 0 & 700 & 452 & 75 \\
\hline & & Huludao & 1023 & 435 & 0 & 0 & 0 & 588 & 3 & 0 \\
\hline & & Panjin & 1498 & 0 & 0 & 0 & 1489 & 0 & 17 & 10 \\
\hline \multirow{4}{*}{$\begin{array}{c}\text { 2.Shandon } \\
\text { g }\end{array}$} & \multirow{4}{*}{ Shandong } & Total & 57337 & 15555 & 235 & 5197 & 6537 & 28690 & 34185 & 1038 \\
\hline & & Qingdao & 22894 & 6822 & 40 & 1041 & 3214 & 11000 & 16912 & 776 \\
\hline & & Yantai & 14345 & 1032 & 130 & 1393 & 1108 & 10500 & 5323 & 108 \\
\hline & & Rizhao & 15904 & 7163 & 65 & 1807 & 1768 & 5000 & 10825 & 102 \\
\hline
\end{tabular}




\begin{tabular}{|c|c|c|c|c|c|c|c|c|c|c|}
\hline & & Weihai & 2009 & 17 & 0 & 694 & 55 & 1200 & 600 & 33 \\
\hline & & Dongying & 715 & 46 & 0 & 64 & 265 & 340 & 200 & 0 \\
\hline & & Binzhou & 283 & 279 & 0 & 0 & 4 & 0 & 0 & 0 \\
\hline & & Langfang & 1171 & 197 & 0 & 198 & 124 & 650 & 325 & 3 \\
\hline \multirow{22}{*}{ 3.YRD } & Shanghai & Shanghai & 38794 & 4715 & 6712 & 6534 & 2427 & 16725 & 18853 & 1681 \\
\hline & \multirow{14}{*}{ Zhejiang } & Total & 967 & 0 & 0 & 0 & 0 & 0 & 20398 & 967 \\
\hline & & Jiaxing & 3023 & 0 & 1916 & 1057 & 0 & 0 & 430 & 51 \\
\hline & & $\begin{array}{l}\text { Ningnbo- } \\
\text { Zhoushan }\end{array}$ & 43200 & 19435 & 0 & 3963 & 4400 & 14535 & 19208 & 868 \\
\hline & & Taizhou & 2815 & 0 & 1688 & 563 & 0 & 555 & 489 & 8 \\
\hline & & Wenzhou & 3686 & 1476 & 0 & 1291 & 0 & 890 & 244 & 29 \\
\hline & & Hangzhou & 4690 & 0 & 610 & 1126 & 844 & 2110 & 0 & 0 \\
\hline & & Jiaxing-river & 5557 & 0 & 3100 & 2150 & 0 & 300 & 0 & 7 \\
\hline & & Huzhou & 7660 & 919 & 6737 & 0 & 0 & 0 & 26 & 4 \\
\hline & & Shaoxing & 672 & 0 & 672 & 0 & 0 & 0 & 0 & 0 \\
\hline & & Ningbo-river & 26 & 0 & 0 & 0 & 0 & 26 & 2 & 0 \\
\hline & & Lanxi & 35 & 0 & 0 & 0 & 0 & 35 & 0 & 0 \\
\hline & & Quzhou & 0 & 0 & 0 & 0 & 0 & 0 & 0 & 0 \\
\hline & & Lishui & 2 & 0 & 0 & 0 & 0 & 2 & 0 & 0 \\
\hline & & Qingtian & 9 & 0 & 0 & 0 & 0 & 9 & 0 & 0 \\
\hline & Hubei & Hubei & 24409 & 6911 & 0 & 1320 & 255 & 15842 & 213 & 54 \\
\hline & Hunan & Hunan & 23097 & 7711 & 0 & 888 & 452 & 14032 & 106 & 15 \\
\hline & \multirow{5}{*}{ Jiangsu } & Total & 70630 & 24313 & 9865 & 25633 & 4445 & 5542 & 7482 & 831 \\
\hline & & Changzhou & 2234 & 992 & 0 & 1235 & 0 & 0 & 237 & 7 \\
\hline & & Jiangyin & 4543 & 1185 & 2903 & 395 & 60 & 0 & 481 & 0 \\
\hline & & Lianyungang & 6463 & 4555 & 1093 & 67 & 274 & 0 & 685 & 472 \\
\hline & & Nanjing & 10553 & 2116 & 1723 & 2747 & 1713 & 2255 & 1118 & 0 \\
\hline
\end{tabular}




\begin{tabular}{|c|c|c|c|c|c|c|c|c|c|}
\hline & Nantong & 6276 & 2937 & 0 & 2621 & 688 & 0 & 665 & 30 \\
\hline & Jiangsu & 11450 & 5721 & 0 & 5220 & 243 & 0 & 1213 & 265 \\
\hline & Taizhou & 4338 & 511 & 0 & 3589 & 230 & 0 & 460 & 9 \\
\hline & Wuxi & 10315 & 1084 & 4146 & 3570 & 498 & 1017 & 1093 & 0 \\
\hline & Suqian & 925 & 736 & 0 & 138 & 51 & 0 & 98 & 0 \\
\hline & Xuzhou & 1320 & 147 & 0 & 1160 & 13 & 0 & 140 & 0 \\
\hline & Yancheng & 2113 & 1443 & 0 & 651 & 16 & 0 & 224 & 3 \\
\hline & Yangzhou & 5003 & 216 & 0 & 2103 & 389 & 2270 & 530 & 26 \\
\hline & Zhenjiang & 5097 & 2672 & 0 & 2137 & 269 & 0 & 540 & 19 \\
\hline Jiangxi & Jiangxi & 8676 & 561 & 2600 & 745 & 91 & 4665 & 17 & 14 \\
\hline Sichuan & Sichuan & 2392 & 114 & 45 & 193 & 27 & 2000 & 0 & 13 \\
\hline \multirow{16}{*}{ Anhui } & Total & 19839 & 4397 & 6441 & 2799 & 262 & 5910 & 0 & 26 \\
\hline & An`qing & 1505 & 96 & 323 & 256 & 128 & 700 & 0 & 2 \\
\hline & Chizhou & 1958 & 551 & 451 & 169 & 24 & 762 & 0 & 1 \\
\hline & Tongling & 2954 & 509 & 466 & 459 & 11 & 1506 & 0 & 1 \\
\hline & Wuhu & 4675 & 1279 & 790 & 874 & 61 & 1653 & 0 & 14 \\
\hline & Ma`an`shan & 3748 & 1439 & 1381 & 384 & 13 & 529 & 0 & 4 \\
\hline & Hefei & 1061 & 184 & 330 & 75 & 15 & 453 & 0 & 5 \\
\hline & Fuyang & 510 & 1 & 413 & 56 & 1 & 38 & 0 & 0 \\
\hline & Liuan & 180 & 81 & 90 & 0 & 0 & 9 & 0 & 0 \\
\hline & Huainan & 808 & 1 & 303 & 394 & 0 & 110 & 0 & 0 \\
\hline & Bengbu & 372 & 1 & 266 & 15 & 0 & 89 & 0 & 0 \\
\hline & Chuzhou & 1308 & 22 & 1029 & 25 & 0 & 232 & 0 & 0 \\
\hline & Xuancheng & 75 & 18 & 43 & 0 & 0 & 14 & 0 & 0 \\
\hline & Bozhou & 521 & 0 & 448 & 37 & 0 & 36 & 0 & 0 \\
\hline & Xiuzhou & 659 & 0 & 104 & 555 & 0 & 0 & 0 & 0 \\
\hline & Huangshan & 6 & 0 & 4 & 0 & 0 & 2 & 0 & 0 \\
\hline
\end{tabular}




\begin{tabular}{|c|c|c|c|c|c|c|c|c|c|c|}
\hline \multirow{5}{*}{$\begin{array}{c}\text { 4.Western } \\
\text { Taiwan } \\
\text { Strait }\end{array}$} & \multirow{5}{*}{ Fujian } & total & 23322 & 2185 & 0 & 4183 & 1389 & 14980 & 9282 & 585 \\
\hline & & Fuzhou & 6478 & 1624 & 0 & 1569 & 99 & 3089 & 2978 & 99 \\
\hline & & Xiamen & 9970 & 368 & 0 & 1195 & 224 & 7757 & 4687 & 400 \\
\hline & & Quanzhou & 5487 & 193 & 0 & 690 & 701 & 3818 & 1195 & 85 \\
\hline & & Putian & 1412 & 0 & 0 & 730 & 366 & 316 & 422 & 0 \\
\hline \multirow{22}{*}{ 5.PRD } & \multirow{22}{*}{ Guangdong } & Total & 78184 & 6163 & 27109 & 12022 & 7606 & 22440 & 25277 & 2476 \\
\hline & & Guanzhou & 23599 & 3668 & 4149 & 3876 & 913 & 10117 & 5731 & 775 \\
\hline & & Shenzhen & 11662 & 421 & 6587 & 215 & 669 & 2606 & 9087 & 1164 \\
\hline & & Zhuhai & 5011 & 134 & 1204 & 811 & 691 & 2128 & 1018 & 44 \\
\hline & & Foshan & 2737 & 12 & 654 & 431 & 257 & 1247 & 1123 & 138 \\
\hline & & Dongguan & 5594 & 8 & 2626 & 2152 & 500 & 201 & 1070 & 99 \\
\hline & & Zhongshan & 3438 & 0 & 2315 & 118 & 123 & 816 & 338 & 66 \\
\hline & & Jiangmen & 3369 & 0 & 1941 & 858 & 142 & 381 & 447 & 47 \\
\hline & & Huizhou & 4023 & 3 & 1205 & 350 & 1941 & 516 & 930 & 8 \\
\hline & & Zhaoqing & 1477 & 6 & 869 & 173 & 38 & 356 & 136 & 35 \\
\hline & & Shantou & 2519 & 0 & 692 & 693 & 64 & 1006 & 714 & 64 \\
\hline & & Chaozhou & 525 & 0 & 0 & 438 & 26 & 61 & 317 & 0 \\
\hline & & Jieyang & 1255 & 0 & 286 & 317 & 149 & 504 & 0 & 0 \\
\hline & & Shanwei & 334 & 0 & 0 & 329 & 5 & 0 & 69 & 1 \\
\hline & & Yangjiang & 1028 & 393 & 24 & 321 & 24 & 267 & 582 & 0 \\
\hline & & Zhanjiang & 9003 & 1515 & 3875 & 682 & 1153 & 1664 & 2987 & 23 \\
\hline & & Maoming & 1185 & 1 & 0 & 88 & 733 & 358 & 637 & 5 \\
\hline & & Shaoguan & 40 & 0 & 0 & 39 & 0 & 0 & 0 & 0 \\
\hline & & Heyuan & 0 & 0 & 0 & 0 & 0 & 0 & 0 & 0 \\
\hline & & Meizhou & 63 & 0 & 50 & 0 & 0 & 13 & 0 & 0 \\
\hline & & Qingyuan & 504 & 0 & 212 & 106 & 0 & 21 & 0 & 1 \\
\hline & & Yunfu & 818 & 3 & 424 & 26 & 178 & 182 & 91 & 6 \\
\hline
\end{tabular}




\begin{tabular}{|c|c|c|c|c|c|c|c|c|c|c|}
\hline \multirow{11}{*}{$\begin{array}{c}\text { 6.Beibu } \\
\text { Gulf }\end{array}$} & \multirow{8}{*}{ Guangxi } & Total & 5387 & 1117 & 1156 & 2325 & 31 & 677 & 2574 & 78 \\
\hline & & Fangcheng & 3485 & 0 & 0 & 0 & 0 & 0 & 0 & 45 \\
\hline & & Qinzhou & 722 & 0 & 0 & 0 & 0 & 0 & 0 & 0 \\
\hline & & Beihai & 613 & 0 & 0 & 0 & 0 & 0 & 0 & 0 \\
\hline & & Guigang & 349 & 42 & 17 & 262 & 6 & 18 & 192 & 6 \\
\hline & & Liuzhou & 22 & 22 & 0 & 0 & 0 & 0 & 8 & 0 \\
\hline & & Nanning & 27 & 3 & 0 & 23 & 0 & 0 & 9 & 0 \\
\hline & & Wuzhou & 123 & 4 & 0 & 55 & 26 & 20 & 43 & 20 \\
\hline & Guizhou & Guizhou & 492 & 0 & 0 & 0 & 0 & 492 & 0 & 0 \\
\hline & Hainan & Hainan & 6420 & 0 & 2183 & 1733 & 321 & 1965 & 1187 & 71 \\
\hline & Yunnan & Yunnan & 247 & 0 & 0 & 0 & 0 & 247 & 0 & 0 \\
\hline
\end{tabular}

* Data from China port statistical yearbook in 2014.

Table SI-5(b) raw data of transport volume for emission trends estimation in 2013

\begin{tabular}{|c|c|c|c|c|c|c|c|c|c|c|}
\hline \multirow{2}{*}{2013} & \multirow[t]{2}{*}{ Port clusters } & \multirow{2}{*}{ Ports } & \multirow{2}{*}{ Total } & \multirow{2}{*}{$\begin{array}{l}\text { Liquid } \\
\text { cargo }\end{array}$} & \multirow{2}{*}{ Bulk cargo } & \multirow{2}{*}{$\begin{array}{c}\text { General } \\
\text { cargo }\end{array}$} & \multicolumn{2}{|c|}{ Container } & \multicolumn{2}{|c|}{ Car } \\
\hline & & & & & & & $10 \mathrm{k}$ TEU & Weight & Number(10t) & Weight \\
\hline Unit:10kt & & Total & 588353 & 47390 & 345523 & 58345 & 9511 & 109244 & 792 & 27852 \\
\hline \multirow{9}{*}{ Coast ports } & & Sum & 378065 & 37413 & 187844 & 29557 & 8484 & 97347 & 726 & 25905 \\
\hline & Bohai & Tianjin & 25032 & 3033 & 11383 & 1568 & 651 & 7608 & 46 & 1441 \\
\hline & Bohai & Hebei & 44492 & 1182 & 40138 & 2147 & 68 & 1026 & 0 & 0 \\
\hline & Bohai & Liaoning & 49177 & 5687 & 17180 & 6139 & 899 & 14191 & 90 & 5981 \\
\hline & YRD & Shanghai & 34137 & 1621 & 11952 & 2707 & 1681 & 17122 & 70 & 737 \\
\hline & YRD & Jiangsu & 11954 & 167 & 8005 & 1014 & 277 & 2768 & 0 & 0 \\
\hline & YRD & Zhejiang & 50296 & 7796 & 28072 & 2144 & 955 & 9830 & 117 & 2454 \\
\hline & WTS & Fujian & 22738 & 1359 & 11071 & 2610 & 585 & 7445 & 22 & 253 \\
\hline & Shandong & Shandong & 59069 & 6966 & 30101 & 4308 & 1038 & 11379 & 87 & 6315 \\
\hline
\end{tabular}




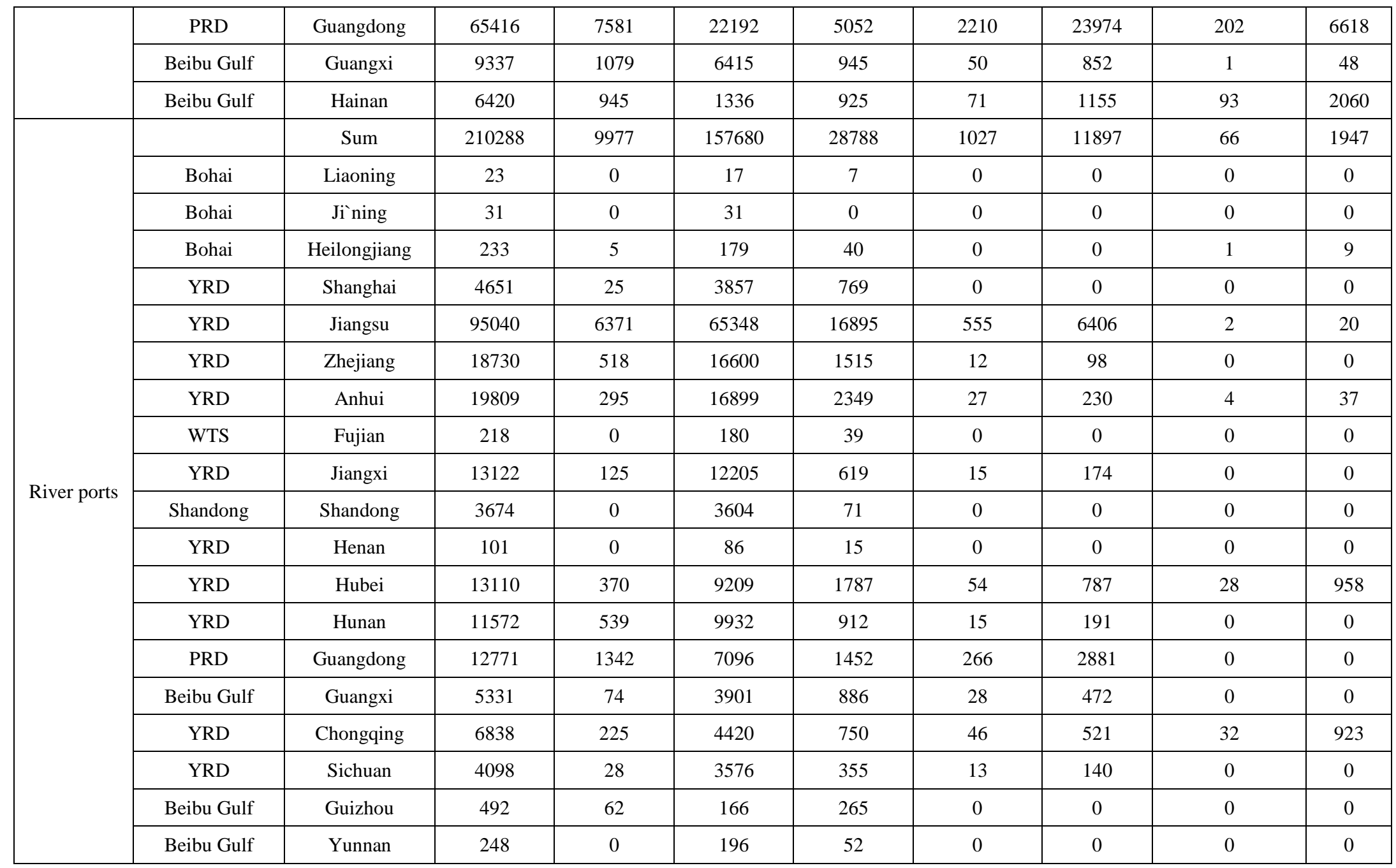

* Data from China port statistical yearbook in 2014. WTS is "Western taiwan strait"

Table SI-5(c) raw data of transport volume in 2012

\begin{tabular}{|l|l|l|l|l|l|l|l|l|}
\hline 2012 & Port clusters & Ports & Total & & Bulk cargo & & Container \\
\hline
\end{tabular}




\begin{tabular}{|c|c|c|c|c|c|c|c|c|c|c|}
\hline & & & & $\begin{array}{l}\text { Liquid } \\
\text { cargo }\end{array}$ & & $\begin{array}{c}\text { General } \\
\text { cargo }\end{array}$ & 10k TEU & Weight & Number(10t) & Weight \\
\hline Unit:10kt & & Total & 538802 & 45313 & 314550 & 53218 & 8874 & 99074 & 757 & 26649 \\
\hline \multirow{12}{*}{ Coast ports } & & Sum & 343988 & 35913 & 168320 & 26802 & 7899 & 87993 & 697 & 24960 \\
\hline & Bohai & Tianjin & 23849 & 3071 & 11208 & 1561 & 615 & 6721 & 42 & 1288 \\
\hline & Bohai & Hebei & 38117 & 1213 & 34105 & 2124 & 45 & 676 & 0 & 0 \\
\hline & Bohai & Liaoning & 44251 & 5337 & 15401 & \#VALUE! & 757 & 12367 & 76 & 5217 \\
\hline & YRD & Shanghai & 31870 & 1624 & 10806 & 2521 & 1627 & 16240 & 64 & 680 \\
\hline & YRD & Jiangsu & 10252 & 200 & 6735 & 812 & 252 & 2506 & 0 & 0 \\
\hline & YRD & Zhejiang & 46380 & 7567 & 25267 & 1971 & 880 & 8906 & 130 & 2671 \\
\hline & WTS & Fujian & 20680 & 1340 & 10113 & 2235 & 537 & 6654 & 29 & 338 \\
\hline & Shandong & Shandong & 53328 & 6156 & 27034 & 3395 & 950 & 9956 & 86 & 6788 \\
\hline & PRD & Guangdong & 60633 & 7147 & 20449 & 4699 & 2128 & 22248 & 189 & 6091 \\
\hline & Beibu Gulf & Guangxi & 8719 & 1149 & 6003 & 845 & 41 & 679 & 1 & 45 \\
\hline & Beibu Gulf & Hainan & 5910 & 1111 & 1202 & 712 & 69 & 1042 & 82 & 1844 \\
\hline \multirow{12}{*}{ River ports } & & Sum & 194815 & 9400 & 146230 & 26416 & 975 & 11081 & 60 & 1689 \\
\hline & Bohai & Liaoning & 25 & 0 & 15 & 10 & 0 & 0 & 0 & 0 \\
\hline & Bohai & Ji`ning & 32 & 0 & 32 & 0 & 0 & 0 & 0 & 0 \\
\hline & Bohai & Heilongjiang & 232 & \#VALUE! & 172 & 40 & 0 & 1 & 1 & 15 \\
\hline & YRD & Shanghai & 4910 & 37 & 4077 & 797 & 0 & 0 & 0 & 0 \\
\hline & YRD & Jiangsu & 87457 & 6709 & 60395 & 14070 & 548 & 6278 & 1 & 7 \\
\hline & YRD & Zhejiang & 19586 & 325 & 17031 & 2170 & 7 & 61 & 0 & 0 \\
\hline & YRD & Anhui & 18049 & 285 & 15030 & 2506 & 23 & 194 & 4 & 36 \\
\hline & WTS & Fujian & 230 & 0 & 184 & 45 & 0 & 0 & 0 & 0 \\
\hline & YRD & Jiangxi & 12636 & 136 & 11842 & 530 & 12 & 128 & 0 & 0 \\
\hline & Shandong & Shandong & 3301 & 0 & 3257 & 45 & 0 & 0 & 0 & 0 \\
\hline & YRD & Henan & 118 & 0 & 81 & 38 & 0 & 0 & 0 & 0 \\
\hline
\end{tabular}




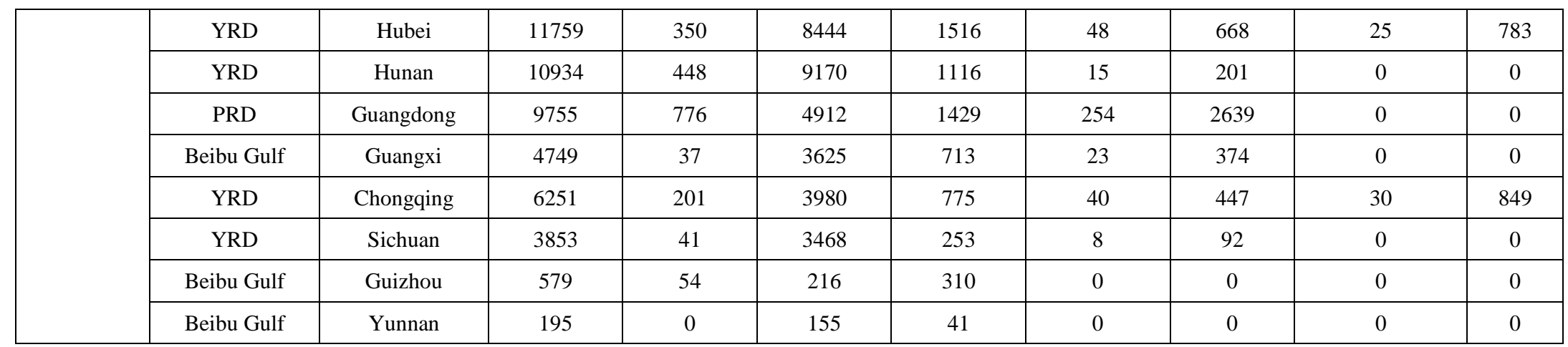

* Data from China port statistical yearbook in 2013.

Table SI-5(d) raw data of transport volume in 2011

\begin{tabular}{|c|c|c|c|c|c|c|c|c|c|c|}
\hline \multirow{2}{*}{2011} & \multirow[t]{2}{*}{ Port clusters } & \multirow{2}{*}{ Ports } & \multirow{2}{*}{ Total } & \multirow{2}{*}{$\begin{array}{c}\text { Liquid } \\
\text { cargo }\end{array}$} & \multirow{2}{*}{ Bulk cargo } & \multirow{2}{*}{$\begin{array}{c}\text { General } \\
\text { cargo }\end{array}$} & \multicolumn{2}{|c|}{ Container } & \multicolumn{2}{|c|}{ Car } \\
\hline & & & & & & & 10k TEU & Weight & Number(10t) & Weight \\
\hline Unit:10kt & & Total & 502057 & 45539 & 292744 & 50875 & 8184 & 88727 & 732 & 24172 \\
\hline \multirow{11}{*}{ Coast ports } & & Sum & 318012 & 36314 & 153776 & 26500 & 7316 & 78985 & 669 & 22438 \\
\hline & Bohai & Tianjin & 22669 & 3239 & 10795 & 1480 & 580 & 5965 & 38 & 1192 \\
\hline & Bohai & Hebei & 35650 & 1143 & 32012 & 1870 & 39 & 626 & 0 & 0 \\
\hline & Bohai & Liaoning & 39172 & 5251 & 14275 & 5590 & 600 & 9558 & 65 & 4500 \\
\hline & YRD & Shanghai & 31216 & 1654 & 10703 & 2657 & 1587 & 15610 & 56 & 592 \\
\hline & YRD & Jiangsu & 8876 & 121 & 5327 & 1116 & 244 & 2313 & 0 & 0 \\
\hline & YRD & Zhejiang & 43350 & 8217 & 22088 & 2381 & 792 & 7874 & 133 & 2792 \\
\hline & WTS & Fujian & 18640 & 1278 & 8554 & 2416 & 485 & 6050 & 30 & 343 \\
\hline & Shandong & Shandong & 48094 & 5253 & 24807 & 3580 & 846 & 8869 & 74 & 5587 \\
\hline & PRD & Guangdong & 57228 & 7982 & 18646 & 4271 & 2052 & 20658 & 195 & 5673 \\
\hline & Beibu Gulf & Guangxi & 7666 & 1108 & 5425 & 503 & 37 & 583 & 1 & 49 \\
\hline
\end{tabular}




\begin{tabular}{|c|c|c|c|c|c|c|c|c|c|c|}
\hline & Beibu Gulf & Hainan & 5453 & 1072 & 1148 & 638 & 56 & 882 & 78 & 1713 \\
\hline \multirow{20}{*}{ River ports } & & Sum & 184045 & 9225 & 138969 & 24375 & 868 & 9743 & 64 & 1734 \\
\hline & Bohai & Liaoning & 15 & 0 & 11 & 4 & 0 & 0 & 0 & 0 \\
\hline & Bohai & Ji`ning & 35 & 0 & 35 & 0 & 0 & 0 & 0 & 0 \\
\hline & Bohai & Heilongjiang & 229 & 5 & 161 & 48 & 0 & 1 & 1 & 16 \\
\hline & YRD & Shanghai & 5163 & 67 & 4404 & 693 & 0 & 0 & 0 & 0 \\
\hline & YRD & Jiangsu & 81466 & 6791 & 55593 & 13774 & 465 & 5304 & 1 & 6 \\
\hline & YRD & Zhejiang & 17837 & 311 & 15634 & 1871 & 3 & 22 & 0 & 0 \\
\hline & YRD & Anhui & 18710 & 278 & 16308 & 1908 & 20 & 172 & 5 & 46 \\
\hline & WTS & Fujian & 209 & 0 & 154 & 55 & 0 & 0 & 0 & 0 \\
\hline & YRD & Jiangxi & 11779 & 103 & 11064 & 494 & 10 & 119 & 0 & 0 \\
\hline & Shandong & Shandong & 3219 & 0 & 3023 & 196 & 0 & 0 & 0 & 0 \\
\hline & YRD & Henan & 101 & 0 & 92 & 9 & 0 & 0 & 0 & 0 \\
\hline & YRD & Hubei & 10832 & 287 & 7825 & 1340 & 43 & 589 & 27 & 790 \\
\hline & YRD & Hunan & 10532 & 215 & 9448 & 711 & 12 & 159 & 0 & 0 \\
\hline & PRD & Guangdong & 9625 & 861 & 4840 & 1310 & 256 & 2614 & 0 & 0 \\
\hline & Beibu Gulf & Guangxi & 4014 & 41 & 3008 & 660 & 21 & 305 & 0 & 0 \\
\hline & YRD & Chongqing & 5803 & 177 & 3571 & 783 & 34 & 395 & 31 & 878 \\
\hline & YRD & Sichuan & 3538 & 48 & 3200 & 224 & 6 & 66 & 0 & 0 \\
\hline & Beibu Gulf & Guizhou & 546 & 44 & 263 & 240 & 0 & 0 & 0 & 0 \\
\hline & Beibu Gulf & Yunnan & 231 & 0 & 191 & 40 & 0 & 0 & 0 & 0 \\
\hline
\end{tabular}

* Data from China port statistical yearbook in 2012.

Table SI-5(e) raw data of transport volume in 2010

\begin{tabular}{|l|l|l|l|l|l|l|l|l|l|}
\hline \multirow{2}{*}{2010} & Port clusters & Ports & Total & $\begin{array}{c}\text { Liquid } \\
\text { cargo }\end{array}$ & Bulk cargo & $\begin{array}{c}\text { General } \\
\text { cargo }\end{array}$ & \multicolumn{2}{|c|}{ Container } \\
\cline { 6 - 9 } & & & & Wek TEU & Weight & Number(10t) & Weight \\
\hline
\end{tabular}




\begin{tabular}{|c|c|c|c|c|c|c|c|c|c|c|}
\hline Unit:10kt & & Total & 446612 & 42698 & 257659 & 47724 & 7307 & 76590 & 705 & 21941 \\
\hline \multirow{12}{*}{ Coast ports } & & Sum & 282232 & 34274 & 135126 & 23938 & 6573 & 68538 & 649 & 20358 \\
\hline & Bohai & Tianjin & 20663 & 3315 & 9392 & 1472 & 505 & 5458 & 33 & 1026 \\
\hline & Bohai & Hebei & 30172 & 842 & 27382 & 1451 & 31 & 499 & 0 & 0 \\
\hline & Bohai & Liaoning & 33895 & 5156 & 11921 & 4918 & 485 & 7833 & 66 & 4067 \\
\hline & YRD & Shanghai & 28160 & 1564 & 9682 & 2516 & 1454 & 13996 & 38 & 403 \\
\hline & YRD & Jiangsu & 6924 & 175 & 4314 & 530 & 196 & 1905 & 0 & 0 \\
\hline & YRD & Zhejiang & 39423 & 7536 & 19996 & 1883 & 702 & 6138 & 173 & 3871 \\
\hline & WTS & Fujian & 16344 & 1336 & 7196 & 2147 & 434 & 5372 & 25 & 293 \\
\hline & Shandong & Shandong & 43211 & 4950 & 22564 & 4137 & 766 & 7595 & 61 & 3966 \\
\hline & PRD & Guangdong & 52650 & 7768 & 17209 & 3865 & 1934 & 18707 & 181 & 5102 \\
\hline & Beibu Gulf & Guangxi & 5962 & 638 & 4371 & 450 & 28 & 463 & 2 & 41 \\
\hline & Beibu Gulf & Hainan & 4831 & 996 & 1102 & 571 & 41 & 574 & 71 & 1590 \\
\hline \multirow{14}{*}{ River ports } & & Sum & 164380 & 8425 & 122534 & 23787 & 734 & 8052 & 57 & 1583 \\
\hline & Bohai & Liaoning & 81 & 0 & 81 & 0 & 0 & 0 & 0 & 0 \\
\hline & Bohai & Ji`ning & 34 & 0 & 34 & 0 & 0 & 0 & 0 & 0 \\
\hline & Bohai & Heilongjiang & 198 & 6 & 138 & 40 & 0 & 1 & 1 & 2 \\
\hline & YRD & Shanghai & 4510 & 67 & 3730 & 713 & 0 & 0 & 0 & 0 \\
\hline & YRD & Jiangsu & 72565 & 6054 & 47978 & 14332 & 372 & 4195 & 1 & 7 \\
\hline & YRD & Zhejiang & 16971 & 319 & 15343 & 1309 & 0 & 1 & 0 & 0 \\
\hline & YRD & Anhui & 16251 & 304 & 14014 & 1806 & 11 & 103 & 3 & 25 \\
\hline & WTS & Fujian & 191 & 0 & 127 & 65 & 0 & 0 & 0 & 0 \\
\hline & YRD & Jiangxi & 10566 & 111 & 9880 & 469 & 9 & 107 & 0 & 0 \\
\hline & Shandong & Shandong & 3273 & 31 & 2952 & 291 & 0 & 0 & 0 & 0 \\
\hline & YRD & Henan & 70 & 0 & 66 & 4 & 0 & 0 & 0 & 0 \\
\hline & YRD & Hubei & 9392 & 274 & 6398 & 1442 & 39 & 546 & 25 & 733 \\
\hline & YRD & Hunan & 9627 & 260 & 8605 & 629 & 11 & 134 & 0 & 0 \\
\hline
\end{tabular}




\begin{tabular}{|c|c|c|c|c|c|c|c|c|c|}
\hline PRD & Guangdong & 8479 & 792 & 4186 & 1088 & 246 & 2414 & 0 \\
\hline Beibu Gulf & Guangxi & 3354 & 29 & 2565 & 582 & 15 & 179 & 0 \\
\hline YRD & Chongqing & 4834 & 133 & 2995 & 571 & 28 & 331 & 28 \\
\hline YRD & Sichuan & 3194 & 42 & 2929 & 180 & 4 & 44 & 0 \\
\hline Beibu Gulf & Guizhou & 445 & 7 & 216 & 222 & 0 & 0 & 0 \\
\hline Beibu Gulf & Yunnan & 210 & 0 & 173 & 37 & 0 & 0 & 0 \\
\hline
\end{tabular}

* Data from China port statistical yearbook in 2011.

Table SI-5(f) raw data of transport volume in 2009

\begin{tabular}{|c|c|c|c|c|c|c|c|c|c|c|}
\hline \multirow{2}{*}{2009} & \multirow{2}{*}{ Port clusters } & \multirow{2}{*}{ Ports } & \multirow{2}{*}{ Total } & \multirow{2}{*}{$\begin{array}{l}\text { Liquid } \\
\text { cargo }\end{array}$} & \multirow{2}{*}{ Bulk cargo } & \multirow{2}{*}{$\begin{array}{c}\text { General } \\
\text { cargo }\end{array}$} & \multicolumn{2}{|c|}{ Container } & \multicolumn{2}{|c|}{ Car } \\
\hline & & & & & & & 10k TEU & Weight & Number(10t) & Weight \\
\hline Unit:10kt & & Total & 382854 & 37063 & 220221 & 43025 & 6120 & 63764 & 638 & 18739 \\
\hline \multirow{12}{*}{ Coast ports } & & Sum & 243686 & 29477 & 117441 & 22866 & 5510 & 57208 & 579 & 16697 \\
\hline & Bohai & Tianjin & 19056 & 2644 & 9795 & 1592 & 435 & 4436 & 20 & 591 \\
\hline & Bohai & Hebei & 25437 & 513 & 23530 & 961 & 29 & 435 & 0 & 0 \\
\hline & Bohai & Liaoning & 27630 & 4146 & 9075 & 6063 & 406 & 5859 & 36 & 2488 \\
\hline & YRD & Shanghai & 24734 & 1489 & 8416 & 2316 & 1250 & 12310 & 20 & 204 \\
\hline & YRD & Jiangsu & 5854 & 201 & 3506 & 712 & 153 & 1436 & 0 & 0 \\
\hline & YRD & Zhejiang & 35731 & 6972 & 16850 & 1772 & 559 & 4920 & 235 & 5219 \\
\hline & WTS & Fujian & 15271 & 975 & 7843 & 1741 & 358 & 4501 & 18 & 212 \\
\hline & Shandong & Shandong & 36536 & 4265 & 18699 & 3415 & 656 & 6909 & 53 & 3249 \\
\hline & PRD & Guangdong & 44562 & 6954 & 15266 & 3245 & 1618 & 15716 & 136 & 3382 \\
\hline & Beibu Gulf & Guangxi & 4704 & 378 & 3554 & 472 & 18 & 278 & 1 & 23 \\
\hline & Beibu Gulf & Hainan & 4173 & 943 & 909 & 579 & 30 & 411 & 61 & 1332 \\
\hline \multirow{2}{*}{ River ports } & & Sum & 139169 & 7632 & 102781 & 20159 & 610 & 6557 & 60 & 2042 \\
\hline & Bohai & Shanxi & 0 & 0 & 0 & 0 & 0 & 0 & 0 & 0 \\
\hline
\end{tabular}




\begin{tabular}{|c|c|c|c|c|c|c|c|c|c|}
\hline Bohai & Liaoning & 127 & 0 & 127 & 0 & 0 & 0 & 0 & 0 \\
\hline Bohai & Ji`ning & 42 & 0 & 42 & 0 & 0 & 0 & 0 & 0 \\
\hline YRD & Heilongjiang & 179 & 4 & 119 & 45 & 0 & 0 & 1 & 11 \\
\hline YRD & Shanghai & 4869 & 31 & 4229 & 609 & 0 & 0 & 0 & 0 \\
\hline YRD & Jiangsu & 60539 & 5396 & 41454 & 10473 & 287 & 3210 & 1 & 7 \\
\hline YRD & Zhejiang & 16141 & 289 & 14614 & 1238 & 0 & 0 & 0 & 0 \\
\hline WTS & Anhui & 13225 & 233 & 10531 & 2354 & 10 & 95 & 2 & 14 \\
\hline YRD & Fujian & 145 & 0 & 130 & 15 & 0 & 0 & 0 & 0 \\
\hline Shandong & Jiangxi & 7505 & 127 & 6927 & 365 & 8 & 87 & 0 & 0 \\
\hline YRD & Shandong & 2407 & 8 & 2225 & 174 & 0 & 0 & 0 & 0 \\
\hline YRD & Henan & 44 & 0 & 43 & 2 & 0 & 0 & 0 & 0 \\
\hline YRD & Hubei & 8336 & 252 & 5512 & 1193 & 34 & 457 & 19 & 923 \\
\hline PRD & Hunan & 8470 & 242 & 7569 & 550 & 10 & 110 & 0 & 0 \\
\hline Beibu Gulf & Guangdong & 6819 & 863 & 2204 & 1648 & 222 & 2105 & 0 & 0 \\
\hline YRD & Guangxi & 2748 & 18 & 2025 & 554 & 12 & 152 & 0 & 0 \\
\hline YRD & Chongqing & 4306 & 126 & 2277 & 538 & 26 & 299 & 37 & 1067 \\
\hline Beibu Gulf & Sichuan & 2550 & 43 & 2292 & 151 & 3 & 44 & 1 & 21 \\
\hline Beibu Gulf & Guizhou & 389 & 1 & 177 & 211 & 0 & 0 & 0 & 0 \\
\hline & Yunnan & 170 & 0 & 141 & 30 & 0 & 0 & 0 & 0 \\
\hline & Shanxi & 160 & 0 & 145 & 15 & 0 & 0 & 0 & 0 \\
\hline
\end{tabular}

* Data from China port statistical yearbook in 2010.

Table SI-5(g) raw data of transport volume in 2008

\begin{tabular}{|c|c|c|c|c|c|c|c|c|c|}
\hline \multirow{2}{*}{2008} & Port clusters & Ports & Total & \multirow{2}{*}{$\begin{array}{c}\text { Liquid } \\
\text { cargo }\end{array}$} & Bulk cargo & $\begin{array}{c}\text { General } \\
\text { cargo }\end{array}$ & \multicolumn{2}{|c|}{ Container } & \multicolumn{2}{|c|}{ Car TEU } & Weight & Number(10t) & Weight \\
\hline Unit:10kt & & Total & 351119 & 32881 & 198751 & 42542 & 6416 & 63102 & 637 \\
\hline
\end{tabular}




\begin{tabular}{|c|c|c|c|c|c|c|c|c|c|c|}
\hline \multirow{12}{*}{ Coast ports } & & Sum & 224467 & 26045 & 105008 & 23966 & 5837 & 57346 & 565 & 12104 \\
\hline & Bohai & Tianjin & 17797 & 2360 & 8943 & 1940 & 425 & 4296 & 20 & 259 \\
\hline & Bohai & Hebei & 22033 & 525 & 20162 & 902 & 33 & 444 & 0 & 0 \\
\hline & Bohai & Liaoning & 24342 & 3579 & 7606 & 4905 & 372 & 5186 & 44 & 3067 \\
\hline & YRD & Shanghai & 25404 & 1510 & 8282 & 2499 & 1401 & 12996 & 23 & 117 \\
\hline & YRD & Jiangsu & 5385 & 195 & 2849 & 933 & 151 & 1408 & 0 & 0 \\
\hline & YRD & Zhejiang & 32259 & 6413 & 15165 & 2547 & 574 & 4679 & 243 & 3457 \\
\hline & WTS & Fujian & 13535 & 699 & 6686 & 1795 & 372 & 4355 & 0 & 0 \\
\hline & Shandong & Shandong & 32895 & 3765 & 16271 & 3035 & 661 & 7026 & 108 & 2799 \\
\hline & PRD & Guangdong & 42928 & 5823 & 15542 & 4111 & 1810 & 16390 & 70 & 1064 \\
\hline & Beibu Gulf & Guangxi & 4045 & 316 & 2908 & 539 & 17 & 262 & 1 & 22 \\
\hline & Beibu Gulf & Hainan & 3846 & 863 & 597 & 762 & 23 & 307 & 58 & 1320 \\
\hline \multirow{15}{*}{ River ports } & & Sum & 126652 & 6837 & 93743 & 18576 & 579 & 5756 & 72 & 1740 \\
\hline & Bohai & Liaoning & 42 & 0 & 42 & 0 & 0 & 0 & 0 & 0 \\
\hline & Bohai & Ji’ning & 42 & 0 & 42 & 1 & 0 & 0 & 0 & 0 \\
\hline & Bohai & Heilongjiang & 280 & 6 & 188 & 66 & 0 & 0 & 2 & 21 \\
\hline & YRD & Shanghai & 3681 & 40 & 2886 & 756 & 0 & 0 & 0 & 0 \\
\hline & YRD & Jiangsu & 52768 & 4535 & 35294 & 10368 & 275 & 2563 & 1 & 10 \\
\hline & YRD & Zhejiang & 15560 & 236 & 14342 & 982 & 0 & 0 & 0 & 0 \\
\hline & YRD & Anhui & 13634 & 196 & 11959 & 1324 & 12 & 119 & 1 & 36 \\
\hline & WTS & Fujian & 176 & 0 & 157 & 20 & 0 & 0 & 0 & 0 \\
\hline & YRD & Jiangxi & 5997 & 133 & 5472 & 331 & 7 & 61 & 0 & 0 \\
\hline & Shandong & Shandong & 2530 & 0 & 2469 & 61 & 0 & 0 & 0 & 0 \\
\hline & YRD & Henan & 53 & 1 & 50 & 3 & 0 & 0 & 0 & 0 \\
\hline & YRD & Hubei & 7985 & 200 & 5493 & 1124 & 30 & 352 & 29 & 818 \\
\hline & YRD & Hunan & 8012 & 258 & 6949 & 720 & 7 & 85 & 0 & 0 \\
\hline & PRD & Guangdong & 6470 & 1028 & 1942 & 1380 & 210 & 2121 & 0 & 0 \\
\hline
\end{tabular}




\begin{tabular}{|c|c|c|c|c|c|c|c|c|c|}
\hline Beibu Gulf & Guangxi & 2338 & 18 & 1560 & 649 & 10 & 112 & 0 \\
\hline YRD & Chongqing & 3947 & 148 & 2234 & 445 & 27 & 300 & 33 & 820 \\
\hline YRD & Sichuan & 2459 & 38 & 2227 & 133 & 4 & 45 & 7 \\
\hline Beibu Gulf & Guizhou & 379 & 3 & 250 & 126 & 0 & 0 & 0 \\
\hline Beibu Gulf & Yunnan & 158 & 0 & 73 & 66 & 0 & 0 & 18 \\
\hline
\end{tabular}

* Data from China port statistical yearbook in 2009.

Table SI-5(h) raw data of transport volume in 2007

\begin{tabular}{|c|c|c|c|c|c|c|c|c|c|c|}
\hline \multirow{2}{*}{2007} & \multirow[t]{2}{*}{ Port clusters } & \multirow{2}{*}{ Ports } & \multirow{2}{*}{ Total } & \multirow{2}{*}{$\begin{array}{c}\text { Liquid } \\
\text { cargo }\end{array}$} & \multirow{2}{*}{ Bulk cargo } & \multirow{2}{*}{$\begin{array}{c}\text { General } \\
\text { cargo }\end{array}$} & \multicolumn{2}{|c|}{ Container } & \multicolumn{2}{|c|}{ Car } \\
\hline & & & & & & & 10k TEU & Weight & Number(10t) & Weight \\
\hline Unit:10kt & & Total & 314818 & 27657 & 181158 & 35080 & 5459 & 57408 & 506 & 13514 \\
\hline \multirow{12}{*}{ Coast ports } & & Sum & 200491 & 21756 & 96355 & 18883 & 4899 & 51398 & 452 & 12099 \\
\hline & Bohai & Tianjin & 15338 & 1960 & 7400 & 1373 & 380 & 4105 & 22 & 500 \\
\hline & Bohai & Hebei & 19468 & 487 & 17705 & 859 & 29 & 417 & 0 & 0 \\
\hline & Bohai & Liaoning & 21086 & 2820 & 6917 & 3565 & 349 & 5165 & 38 & 2618 \\
\hline & YRD & Shanghai & 24462 & 1313 & 8258 & 2182 & 1279 & 12396 & 35 & 312 \\
\hline & YRD & Jiangsu & 4613 & 124 & 2710 & 629 & 120 & 1149 & 0 & 0 \\
\hline & YRD & Zhejiang & 28944 & 5193 & 14735 & 1820 & 530 & 4844 & 151 & 2354 \\
\hline & WTS & Fujian & 12690 & 703 & 6226 & 1577 & 338 & 4116 & 6 & 66 \\
\hline & Shandong & Shandong & 28199 & 3268 & 14124 & 2375 & 537 & 5777 & 71 & 2656 \\
\hline & PRD & Guangdong & 39143 & 4960 & 13768 & 3420 & 1502 & 14674 & 89 & 2320 \\
\hline & Beibu Gulf & Guangxi & 3260 & 301 & 2304 & 394 & 15 & 244 & 1 & 17 \\
\hline & Beibu Gulf & Hainan & 3284 & 632 & 581 & 577 & 27 & 398 & 48 & 1096 \\
\hline \multirow{3}{*}{ River ports } & & Sum & 114327 & 5838 & 85113 & 16270 & 538 & 5763 & 52 & 1342 \\
\hline & Bohai & Liaoning & 23 & 0 & 22 & 1 & 0 & 0 & 0 & 0 \\
\hline & Bohai & Ji`ning & 69 & 0 & 69 & 0 & 0 & 0 & 0 & 0 \\
\hline
\end{tabular}




\begin{tabular}{|c|c|c|c|c|c|c|c|c|c|}
\hline Bohai & Heilongjiang & 324 & 6 & 235 & 64 & 0 & 0 & 1 & 18 \\
\hline YRD & Shanghai & 3518 & 29 & 2834 & 655 & 0 & 0 & 0 & 0 \\
\hline YRD & Jiangsu & 46053 & 3586 & 31171 & 8680 & 252 & 2607 & 1 & 9 \\
\hline YRD & Zhejiang & 15507 & 332 & 14019 & 1116 & 5 & 40 & 0 & 0 \\
\hline YRD & Anhui & 11816 & 172 & 10244 & 1255 & 13 & 118 & 1 & 27 \\
\hline WTS & Fujian & 133 & 0 & 115 & 18 & 0 & 0 & 0 & 0 \\
\hline YRD & Jiangxi & 6546 & 100 & 6036 & 333 & 7 & 77 & 0 & 0 \\
\hline Shandong & Shandong & 2206 & 0 & 2157 & 49 & 0 & 0 & 0 & 0 \\
\hline YRD & Henan & 44 & 0 & 39 & 4 & 0 & 0 & 0 & 0 \\
\hline YRD & Hubei & 7632 & 202 & 5303 & 1058 & 30 & 394 & 22 & 675 \\
\hline YRD & Hunan & 5973 & 221 & 5163 & 515 & 6 & 75 & 0 & 0 \\
\hline PRD & Guangdong & 6231 & 829 & 2635 & 1031 & 167 & 1736 & 0 & 0 \\
\hline Beibu Gulf & Guangxi & 2103 & 22 & 1463 & 480 & 10 & 138 & 0 & 0 \\
\hline YRD & Chongqing & 3328 & 119 & 1993 & 371 & 22 & 253 & 22 & 593 \\
\hline YRD & Sichuan & 2216 & 26 & 1974 & 152 & 5 & 56 & 3 & 9 \\
\hline Beibu Gulf & Guizhou & 320 & 18 & 169 & 133 & 0 & 0 & 0 & 0 \\
\hline Beibu Gulf & Yunnan & 156 & 0 & 97 & 49 & 0 & 0 & 0 & 10 \\
\hline
\end{tabular}

* Data from China port statistical yearbook in 2008.

Table SI-5(i) raw data of transport volume in 2006

\begin{tabular}{|c|c|c|c|c|c|c|c|c|c|c|}
\hline \multirow{2}{*}{2006} & \multirow[t]{2}{*}{ Port clusters } & \multirow{2}{*}{ Ports } & \multirow{2}{*}{ Total } & \multirow{2}{*}{$\begin{array}{l}\text { Liquid } \\
\text { cargo }\end{array}$} & \multirow{2}{*}{ Bulk cargo } & \multirow{2}{*}{$\begin{array}{c}\text { General } \\
\text { cargo }\end{array}$} & \multicolumn{2}{|c|}{ Container } & \multicolumn{2}{|c|}{ Car } \\
\hline & & & & & & & 10k TEU & Weight & Number(10t) & Weight \\
\hline Unit:10kt & & Total & 278517 & 22434 & 163565 & 27619 & 4502 & 51714 & 375 & 13184 \\
\hline \multirow{3}{*}{ Coast ports } & & Sum & 176516 & 17468 & 87703 & 13800 & 3961 & 45450 & 339 & 12095 \\
\hline & Bohai & Tianjin & 12880 & 1560 & 5857 & 807 & 335 & 3915 & 24 & 741 \\
\hline & Bohai & Hebei & 16903 & 449 & 15248 & 815 & 26 & 390 & 0 & 0 \\
\hline
\end{tabular}




\begin{tabular}{|c|c|c|c|c|c|c|c|c|c|c|}
\hline & Bohai & Liaoning & 17829 & 2062 & 6228 & 2226 & 326 & 5145 & 32 & 2168 \\
\hline & YRD & Shanghai & 23520 & 1117 & 8235 & 1865 & 1158 & 11797 & 48 & 507 \\
\hline & YRD & Jiangsu & 3842 & 54 & 2572 & 326 & 89 & 890 & 0 & 0 \\
\hline & YRD & Zhejiang & 25629 & 3973 & 14305 & 1093 & 487 & 5009 & 59 & 1250 \\
\hline & WTS & Fujian & 11844 & 708 & 5767 & 1360 & 304 & 3878 & 11 & 132 \\
\hline & Shandong & Shandong & 23503 & 2772 & 11977 & 1714 & 413 & 4528 & 34 & 2513 \\
\hline & PRD & Guangdong & 35359 & 4098 & 11995 & 2730 & 1195 & 12958 & 109 & 3577 \\
\hline & Beibu Gulf & Guangxi & 2475 & 286 & 1700 & 250 & 13 & 226 & 0 & 13 \\
\hline & Beibu Gulf & Hainan & 2722 & 401 & 566 & 392 & 30 & 490 & 39 & 873 \\
\hline \multirow{18}{*}{ River ports } & & Sum & 102002 & 4839 & 76483 & 13964 & 498 & 5771 & 32 & 944 \\
\hline & Bohai & Liaoning & 4 & 0 & 3 & 1 & 0 & 0 & 0 & 0 \\
\hline & Bohai & Ji`ning & 97 & 0 & 97 & 0 & 0 & 0 & 0 & 0 \\
\hline & Bohai & Heilongjiang & 367 & 7 & 283 & 63 & 0 & 0 & 1 & 14 \\
\hline & YRD & Shanghai & 3355 & 18 & 2782 & 555 & 0 & 0 & 0 & 0 \\
\hline & YRD & Jiangsu & 39338 & 2637 & 27048 & 6993 & 230 & 2652 & 1 & 8 \\
\hline & YRD & Zhejiang & 15454 & 427 & 13696 & 1250 & 9 & 80 & 0 & 0 \\
\hline & YRD & Anhui & 9998 & 149 & 8529 & 1185 & 13 & 116 & 2 & 19 \\
\hline & WTS & Fujian & 89 & 0 & 73 & 16 & 0 & 0 & 0 & 0 \\
\hline & YRD & Jiangxi & 7096 & 68 & 6600 & 334 & 8 & 94 & 0 & 0 \\
\hline & Shandong & Shandong & 1882 & 0 & 1846 & 36 & 0 & 0 & 0 & 0 \\
\hline & YRD & Henan & 34 & 0 & 29 & 5 & 0 & 0 & 0 & 0 \\
\hline & YRD & Hubei & 7279 & 205 & 5113 & 992 & 30 & 437 & 16 & 532 \\
\hline & YRD & Hunan & 3934 & 183 & 3376 & 310 & 5 & 65 & 0 & 0 \\
\hline & PRD & Guangdong & 5991 & 630 & 3329 & 681 & 125 & 1352 & 0 & 0 \\
\hline & Beibu Gulf & Guangxi & 1868 & 26 & 1366 & 310 & 10 & 165 & 0 & 0 \\
\hline & YRD & Chongqing & 2710 & 89 & 1752 & 297 & 18 & 206 & 12 & 366 \\
\hline & YRD & Sichuan & 1973 & 13 & 1721 & 171 & 6 & 67 & 0 & 0 \\
\hline
\end{tabular}




\begin{tabular}{|l|c|c|c|c|c|c|c|c|c|c|}
\hline & Beibu Gulf & Guizhou & 261 & 33 & 88 & 140 & 0 & 0 & 0 \\
\cline { 2 - 14 } & Beibu Gulf & Yunnan & 153 & 0 & 121 & 32 & 0 & 0 \\
\hline
\end{tabular}

* Data from China port statistical yearbook in 2007.

Table SI-5(g) raw data of transport volume in 2005

\begin{tabular}{|c|c|c|c|c|c|c|c|c|c|c|}
\hline \multirow{2}{*}{2005} & \multirow[t]{2}{*}{ Port clusters } & \multirow{2}{*}{ Ports } & \multirow{2}{*}{ Total } & \multirow{2}{*}{$\begin{array}{l}\text { Liquid } \\
\text { cargo }\end{array}$} & \multirow{2}{*}{ Bulk cargo } & \multirow{2}{*}{$\begin{array}{c}\text { General } \\
\text { cargo }\end{array}$} & \multicolumn{2}{|c|}{ Container } & \multicolumn{2}{|c|}{ Car } \\
\hline & & & & & & & 10k TEU & Weight & Number(10t) & Weight \\
\hline Unit:10kt & & Total & 242694 & 20572 & 149990 & 25327 & 3782 & 34715 & 344 & 12090 \\
\hline \multirow{12}{*}{ Coast ports } & & Sum & 150447 & 15786 & 79260 & 12471 & 3501 & 31999 & 306 & 10930 \\
\hline & Bohai & Tianjin & 12035 & 1629 & 6113 & 842 & 240 & 2677 & 25 & 774 \\
\hline & Bohai & Hebei & 13671 & 369 & 12547 & 671 & 7 & 84 & 0 & 0 \\
\hline & Bohai & Liaoning & 15104 & 2133 & 6445 & 2303 & 189 & 1979 & 34 & 2244 \\
\hline & YRD & Shanghai & 22159 & 1337 & 9858 & 2232 & 904 & 8125 & 58 & 607 \\
\hline & YRD & Jiangsu & 3193 & 48 & 2314 & 293 & 51 & 538 & 0 & 0 \\
\hline & YRD & Zhejiang & 21923 & 3759 & 13537 & 1034 & 278 & 2409 & 56 & 1183 \\
\hline & WTS & Fujian & 9803 & 653 & 5325 & 1255 & 246 & 2448 & 11 & 122 \\
\hline & Shandong & Shandong & 19201 & 2242 & 9686 & 1386 & 377 & 3855 & 28 & 2032 \\
\hline & PRD & Guangdong & 29640 & 3665 & 10729 & 2442 & 1189 & 9605 & 97 & 3199 \\
\hline & Beibu Gulf & Guangxi & 1835 & 221 & 1314 & 194 & 8 & 96 & 0 & 10 \\
\hline & Beibu Gulf & Hainan & 1887 & 305 & 432 & 299 & 14 & 186 & 30 & 665 \\
\hline \multirow{6}{*}{ River ports } & & Sum & 92248 & 4503 & 71159 & 12992 & 281 & 2716 & 30 & 879 \\
\hline & Bohai & Liaoning & 1 & 0 & 0 & 0 & 0 & 0 & 0 & 0 \\
\hline & Bohai & Ji`ning & 48 & 0 & 48 & 0 & 0 & 0 & 0 & 0 \\
\hline & Bohai & Heilongjiang & 456 & 9 & 351 & 78 & 0 & 0 & 1 & 18 \\
\hline & YRD & Shanghai & 5375 & 29 & 4457 & 889 & 0 & 0 & 0 & 0 \\
\hline & YRD & Jiangsu & 34581 & 2411 & 24733 & 6394 & 102 & 1036 & 1 & 8 \\
\hline
\end{tabular}




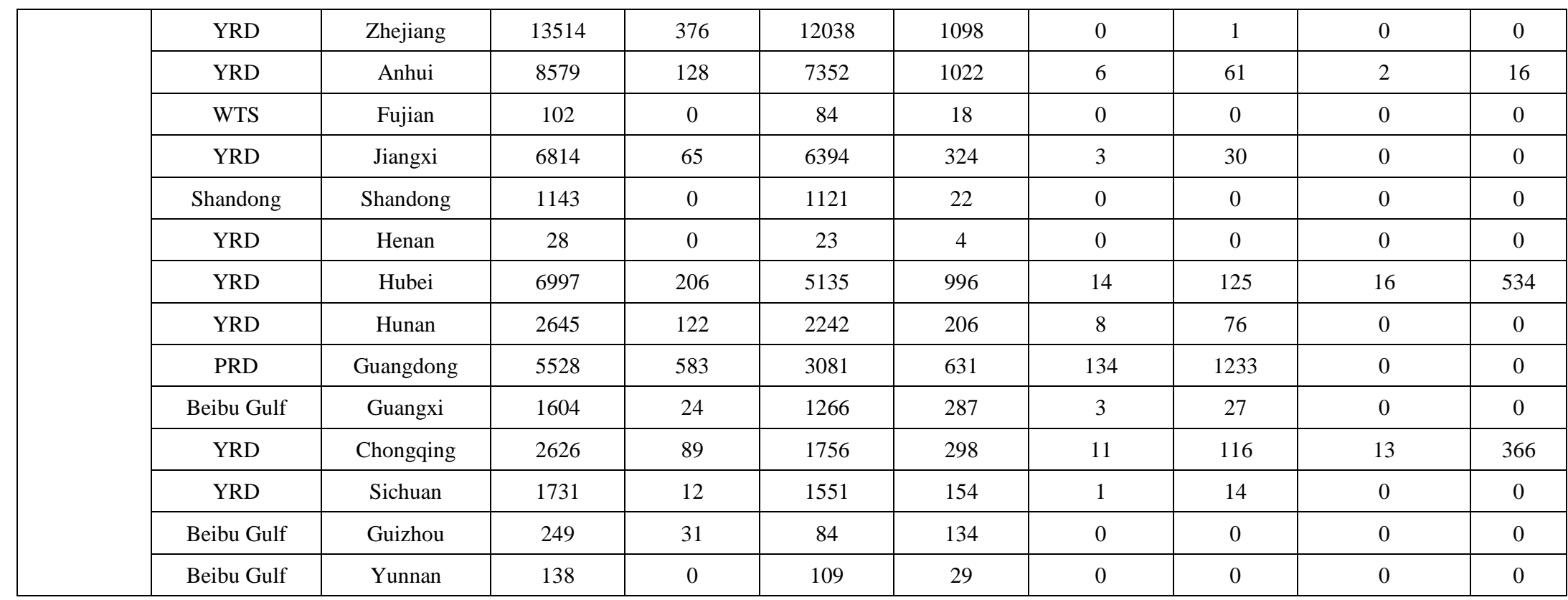

* Data from China port statistical yearbook in 2006.

Table SI-5(k) raw data of transport volume in 2004

\begin{tabular}{|c|c|c|c|c|c|c|c|c|c|c|}
\hline \multirow{2}{*}{2004} & \multirow[t]{2}{*}{ Port clusters } & \multirow{2}{*}{ Ports } & \multirow{2}{*}{ Total } & \multirow{2}{*}{$\begin{array}{l}\text { Liquid } \\
\text { cargo }\end{array}$} & \multirow{2}{*}{ Bulk cargo } & \multirow{2}{*}{$\begin{array}{c}\text { General } \\
\text { cargo }\end{array}$} & \multicolumn{2}{|c|}{ Container } & \multicolumn{2}{|c|}{ Car } \\
\hline & & & & & & & 10k TEU & Weight & Number(10t) & Weight \\
\hline Unit:10kt & & Total & 168034 & 13876 & 101169 & 17083 & 2669 & 27751 & 232 & 8155 \\
\hline \multirow{6}{*}{ Coast ports } & & Sum & 111369 & 11320 & 56837 & 8943 & 2541 & 26430 & 220 & 7838 \\
\hline & Bohai & Tianjin & 8314 & 1064 & 3994 & 550 & 192 & 2200 & 16 & 505 \\
\hline & Bohai & Hebei & 9368 & 251 & 8522 & 456 & 10 & 139 & 0 & 0 \\
\hline & Bohai & Liaoning & 10554 & 1349 & 4076 & 1457 & 164 & 2252 & 21 & 1419 \\
\hline & YRD & Shanghai & 17943 & 947 & 6982 & 1581 & 821 & 8003 & 41 & 430 \\
\hline & YRD & Jiangsu & 2688 & 39 & 1859 & 235 & 55 & 555 & 0 & 0 \\
\hline
\end{tabular}




\begin{tabular}{|c|c|c|c|c|c|c|c|c|c|c|}
\hline & YRD & Zhejiang & 17545 & 2840 & 10226 & 781 & 287 & 2804 & 42 & 894 \\
\hline & WTS & Fujian & 6636 & 419 & 3415 & 805 & 169 & 1919 & 7 & 78 \\
\hline & Shandong & Shandong & 13271 & 1557 & 6730 & 963 & 246 & 2609 & 19 & 1412 \\
\hline & PRD & Guangdong & 22154 & 2644 & 7740 & 1762 & 811 & 7700 & 70 & 2308 \\
\hline & Beibu Gulf & Guangxi & 1403 & 165 & 982 & 145 & 7 & 104 & 0 & 7 \\
\hline & Beibu Gulf & Hainan & 1495 & 229 & 324 & 224 & 14 & 218 & 22 & 500 \\
\hline \multirow{20}{*}{ River ports } & & Sum & 56665 & 2730 & 43152 & 7878 & 220 & 2372 & 18 & 533 \\
\hline & Bohai & Liaoning & 3 & 0 & 2 & 1 & 0 & 0 & 0 & 0 \\
\hline & Bohai & Ji`ning & 16 & 0 & 16 & 0 & 0 & 0 & 0 & 0 \\
\hline & Bohai & Heilongjiang & 152 & 3 & 117 & 26 & 0 & 0 & 0 & 6 \\
\hline & YRD & Shanghai & 3230 & 17 & 2678 & 534 & 0 & 0 & 0 & 0 \\
\hline & YRD & Jiangsu & 24439 & 1669 & 17122 & 4427 & 109 & 1215 & 1 & 5 \\
\hline & YRD & Zhejiang & 8317 & 231 & 7391 & 674 & 2 & 20 & 0 & 0 \\
\hline & YRD & Anhui & 4583 & 68 & 3921 & 545 & 4 & 40 & 1 & 9 \\
\hline & WTS & Fujian & 66 & 0 & 55 & 12 & 0 & 0 & 0 & 0 \\
\hline & YRD & Jiangxi & 2526 & 24 & 2368 & 120 & 1 & 13 & 0 & 0 \\
\hline & Shandong & Shandong & 769 & 0 & 754 & 15 & 0 & 0 & 0 & 0 \\
\hline & YRD & Henan & 9 & 0 & 8 & 1 & 0 & 0 & 0 & 0 \\
\hline & YRD & Hubei & 2332 & 69 & 1712 & 332 & 5 & 42 & 5 & 178 \\
\hline & YRD & Hunan & 2375 & 110 & 2029 & 186 & 5 & 50 & 0 & 0 \\
\hline & PRD & Guangdong & 4239 & 446 & 2358 & 483 & 94 & 951 & 0 & 0 \\
\hline & Beibu Gulf & Guangxi & 986 & 14 & 753 & 171 & 3 & 49 & 0 & 0 \\
\hline & YRD & Chongqing & 875 & 30 & 585 & 99 & 4 & 39 & 4 & 122 \\
\hline & YRD & Sichuan & 1385 & 10 & 1222 & 121 & 3 & 32 & 0 & 0 \\
\hline & Beibu Gulf & Guizhou & 232 & 29 & 78 & 125 & 0 & 0 & 0 & 0 \\
\hline & Beibu Gulf & Yunnan & 100 & 0 & 79 & 21 & 0 & 0 & 0 & 0 \\
\hline
\end{tabular}

* Data from China port statistical yearbook in 2005. 
